Volume 12 | Issue 1

March 2021

\title{
A Review of Literature on the Involvement of Children from Indigenous Communities in Anglo Child Welfare Systems: 1973-2018
}

Vandna Sinha

University of Colorado,Boulder, United States, vandna.sinha@colorado.edu

Johanna Caldwell

McGill University, Canada, johanna.caldwell@mail.mcgill.ca

Leah Paul

McGill University, Canada, leah.paul@mail.mcgill.ca

Paulo Roberto Fumaneri

McGill University, Canada, paulo.fumaneri@mail.mcgill.ca

Recommended Citation

Sinha, V., Caldwell, J., Pauls, L., \& Fumaneri, P. R. (2021). A review of literature on the involvement of children from Indigenous communities in Anglo child welfare systems: 1973-2018. The International Indigenous Policy Journal, 12(1).

https://doi.org/10.18584/iipj.2021.12.1.10818 


\title{
A Review of Literature on the Involvement of Children from Indigenous Communities in Anglo Child Welfare Systems: 1973-2018
}

\begin{abstract}
A series of recent legal and policy developments in Canada have potential to contribute to reconciliation efforts, particularly related to the overrepresentation of Indigenous children in child welfare systems. However, systematic collection, analysis, and synthesis of research knowledge - particularly, research that is locally grounded — on Indigenous child welfare involvement is notably missing from these efforts. With the aim of collating existing research knowledge on this topic, this scoping review of literature includes a broad swath of literature spanning decades (1973-2018) and countries with similar settler colonial histories (Canada, the United States, Australia, and New Zealand). Our search yielded 881 unique research publications. There was an increase in the number of publications over time in all four countries and a trend toward more empirical literature than non-empirical literature. We found that a plurality of publications focused on programs and services $(n=191)$, and policy or legal $(n=168)$ themes. While our review highlights a large base of literature on Indigenous child welfare involvement, it also illustrates the limits of the academic literature in representing the knowledge and experience of Indigenous Peoples and the need for more comprehensive synthesis and broader dissemination of the research related to Indigenous child welfare. These limitations restrict the extent to which existing research can inform the meaningful development of Indigenous child welfare policy in Canada. Due to these gaps, we advocate sustained investment in efforts to synthesize diverse sources of knowledge, support for open source publications, and structural support for Indigenous control of knowledge collection and dissemination regarding policy development related to their communities.
\end{abstract}

\section{Keywords}

Child welfare research, child welfare system, settler colonial history, overrepresentation, epistemology, Canada, the United States, Australia, New Zealand

\section{Creative Commons License} (c) $(1) \Theta \Theta$

This work is licensed under a Creative Commons Attribution-Noncommercial-No Derivative Works 4.0 License. 


\section{A Review of Literature on the Involvement of Children from Indigenous Communities in Anglo Child Welfare Systems: 1973-2018}

In Canada, there are new possibilities for research to support policy development in order to redress entrenched patterns of overrepresentation of Indigenous children in child welfare systems. The context of Indigenous child welfare in Canada is rapidly evolving due to recent legal decisions, legislative changes, and growing public attention to intergenerational harm resulting from settler colonial actions. Specifically, a series of decisions ${ }^{1}$ by the Canadian Human Rights Tribunal have led to rapid funding increases for historically underfunded First Nations child welfare agencies, although these funding shifts are limited in their reach and inclusion of non-First Nations Indigenous communities. ${ }^{2} \mathrm{New}$ federal Canadian child welfare legislation, passed in June 2019, creates potential for recognition of Indigenous self-determination in child welfare (Bill C-92, 2019). There has been an increase in public discussion of reconciliation, most notably as a result of the Truth and Reconciliation Commission of Canada (TRC), which heard testimony from hundreds of Indigenous people who were removed from their families and placed in residential schools where they were often violently abused and neglected. In the TRC's (2015) Calls to Action, the first five recommendations relate to Indigenous child welfare reforms. These recent developments may lead to tangible shifts in policy and practice for Indigenous child welfare involvement in Canada.

However, the base of existing research that could inform the development of new programs and policies is still limited due to several structural realities. First, the lack of a federalized child protection system in Canada means that child welfare data and policy are decentralized, resulting in a fragmented knowledge base. In Canada, underinvestment in child welfare data and data related to Indigenous children in particular is also an important barrier to understanding Indigenous involvement in child welfare systems. Whereas the U.S. has multiple, regular, national sources of child welfare data, ${ }^{3}$ Canada has no comprehensive federal-level child welfare database. Further, 11 years have passed between national-level child welfare studies in Canada. ${ }^{4}$ In addition, provincial and territorial administrative data sometimes still excludes on-reserve First Nation children, and complementary datasets focused on child health and wellbeing have also excluded on-reserve populations (de la Sablonnière-Griffin et al., 2016; Jones \& Sinha, 2015). Finally, to our knowledge, there has been no systematic effort to compile, analyze, and synthesize Indigenous child welfare research produced at the local (community or agency) level.

Examination of the parallel histories across similar settler colonial settings may be relevant to the

\footnotetext{
${ }^{1}$ See First Nations Child and Family Caring Society and Assembly of First Nations v. Attorney General of Canada, 2016, CHRT 2; 2016, CHRT 10; 2016, CHRT 16; 2017, CHRT 7; 2017, CHRT 14; 2018, CHRT 4; 2019, CHRT 7; 2019, CHRT 39.

${ }^{2}$ First Nations are the largest group of federally recognized Indigenous Peoples in Canada, with Inuit and Métis being the others.

${ }^{3}$ These include the National Data Archive on Child Abuse and Neglect (NDACAN), which houses and distributes national-level datasets including the National Child Abuse and Neglect Data System (NCANDS), the National Incidence Study of Child Abuse and Neglect (NIS), the National Survey of Child and Adolescent WellBeing (NSCAW), the Adoption and Foster Care Analysis and Reporting System (AFCARS), and the National Youth in Transition Database (NYTD; National Data Archive on Child Abuse and Neglect, 2020).

${ }^{4}$ The last Canadian Incidence Study of Child Abuse and Neglect (CIS), a survey of select agencies, took place in 2008 and data collection for a subsequent study began in 2019 (Canadian Child Welfare Research Portal, n.d.).
} 
development of policy supporting Indigenous self-determination in Canada. Settler colonial histories in Canada, the United States, Australia, and New Zealand have systematically disrupted traditional ways of life, community, spiritual practices, and family structures for Indigenous Peoples. This pattern has been described as cultural genocide (Bintarsari, 2018; Rensink, 2011; Reyhner \& Singh, 2010; TRC, 2015). In particular, colonial school systems in these countries grew out of missionary efforts to convert and "civilize" Indigenous Peoples: in Canada, the U.S., Australia, and New Zealand, State school systems were key mechanisms of assimilating Indigenous children into settler society (Adams, 1995; Milloy, 2017; Trafzer et al., 2006; van Krieken, 1999a, 1999b).

These settler colonial institutions implemented assimilation policies designed to separate children from their languages, spiritual and land-based practices, and community and familial networks. Since the mid$20^{\text {th }}$ century, child welfare systems in these four countries have increased State involvement in the lives of Indigenous families. These systems have functioned to extend the impact of settler colonial intervention in Indigenous families, and it has had disproportionate impacts on Indigenous communities (Cram et al., 2015; Landertinger, 2016; Tilbury, 2009; White, 2017). Specifically, separation of Indigenous children from their families, and often from their communities, through child welfare intervention is a much more frequent occurrence than for non-Indigenous children in each of these countries (Australian Institute of Family Studies, 2020; Children's Commissioner, 2016; Ministry of Social Development, 2017; Statistics Canada, 2018; Wildeman \& Emanuel, 2014). The removal of children by the child welfare system has, in many ways, perpetuated the destruction of Indigenous community ties and local decision-making.

There are several potential resources that may help elucidate the state of knowledge on Indigenous children and child welfare. Academic research from countries with a shared history of colonization and Indigenous child removal represents one source. In recent years, there have been several notable efforts to compile and synthesize elements of the existing literature on Indigenous child welfare (e.g., Haight et al., 2018; di Tomasso \& de Finney, 2015a, 2015b; Fiolet et al., 2019; Gatwiri et al., 2019; Macvean et al., 2017; Ritland et al., 2020). Each of these reviews makes an important contribution to the existing knowledge base. However, they have all been relatively limited in the number of studies they examined and in the scope of the topics and literature considered, which may be an artifact of the strict selection criteria applied in reviews to distill them to the most rigorous research. While these reviews comment on the inadequacy of existing literature in reflecting the varied lived experiences of Indigenous children, families, and communities, they may be missing existing literature that does contain crucial insights important for understanding Indigenous involvement in child welfare systems.

The task remains to create systematic links among the various forms of knowledge related to Indigenous children and families and broader research literature. This article is an attempt to take stock of existing literature on Indigenous child welfare involvement in Canada and in other comparable settler colonial settings over the past several decades. While we are writing from North America, we are interested in contexts similar to the U.S. and Canada and extend our analysis to Australia and New Zealand accordingly. We take a broad approach to identifying themes in the existing literature and suggest areas in which further synthesis may be warranted and useful. In particular, we examine the nature of literature prioritized in academic research spaces and the value assigned to empirical literature. We also aim to analyze and acknowledge what is being left out when mainstream standards around systematic review are applied to this field (e.g., all the literature produced by and with Indigenous communities but not 
published in mainstream academic journals). As a group of non-Indigenous scholars, we attempt to illustrate what is accessible when searching from within a Western, academic epistemological paradigm while acknowledging the great extent to which important sources of knowledge are deprioritized or missed entirely when doing so. We hope that the synthesis and analysis presented here will support ongoing work by Indigenous communities and scholars in order to move beyond a Western paradigm and highlight existing and new sources of knowledge that are grounded in Indigenous perspectives and experiences.

\section{Settler Colonial Legacies and State-Sponsored Indigenous Child Welfare Involvement}

Canada, the United States, Australia, and New Zealand are bound by similar histories of settler colonial policies and practices that have harmed Indigenous children, families, and communities. Indigenous Peoples continue to deal with the traumas of forced child removal and inappropriate child welfare service provisions, resulting in the overrepresentation of Indigenous children across child welfare systems (Australian Institute of Family Studies, 2020; Children's Commissioner, 2016; Ministry of Social Development, 2017; Statistics Canada, 2018; Wildeman \& Emanuel, 2014). Histories of settler colonial intervention that systematically separate and disrupt Indigenous families and communities in these countries are well documented (Buti, 2002; Jacobs, 2006; Milloy, 2017; Simon \& Smith, 2001). Structural legacies of poverty and intergenerational trauma-imposed by current and historical settler colonial policies and practices resulting in losses of land, culturally based systems of knowledge and care, and community ties - shape a context in which Indigenous children today are overrepresented in child welfare systems (Bombay et al., 2013; Brittain \& Blackstock, 2015; Johnston, 1983; Milloy, 2017; Navia et al., 2018). In recent decades, a transition toward some Indigenous communities taking over jurisdiction of child welfare systems, along with some political endorsement of increased Indigenous self-determination, has accompanied shifts in both recognition of these traumatic histories and possibilities for redressing them (Libesman, 2014; MacDonald \& Levasseur, 2014; Rae, 2009). A brief overview of the strikingly similar colonial histories and ongoing child welfare involvement of Indigenous children in these countries demonstrates the importance of better understanding how these patterns are documented, by whom, and for what purposes.

Beginning in the $19^{\text {th }}$ century, State-sponsored education systems served to assimilate Indigenous Peoples into colonial societies. The residential school system in Canada, boarding schools in the U.S., missions in Australia, and Native schools in New Zealand ${ }^{5}$ resulted in hundreds of thousands of children losing ties with their culture, language, land, and communities. From the mid-1800s to well into the $20^{\text {th }}$ century, Native American children were systematically forced into residential schools off reserve in the United States. In 1973 alone, 60,000 Native American children were enrolled in residential schools. In Canada, an estimated 150,000 Indigenous children attended residential schools (TRC, 2015). In Australia, poor record keeping makes it impossible to know the exact number of children removed (Read, 2006), but one estimate is that at least 100,000 Aboriginal children were removed from their

\footnotetext{
${ }^{5}$ In New Zealand, the structure of the schools was different: There were not as many boarding schools, settler and Indigenous children were often in schools together, and Indigenous adults sometimes had a role in the schools (see for example May et al., 2014; Smith, 2009). However, infant schools in New Zealand played a predominant role in assimilation, with very young children being "the best soil for cultivation," as one $19^{\text {th }}$ century missionary wrote (May et al., 2014, p. 197).
} 
families to attend residential schools between the late 1800s and the 1960s (e.g., Human Rights and Equal Opportunity Commission [HREOC], 1997) under the guise of child protection by the State. In New Zealand, schools were established to "educate" Māori children. The number of Māori children who attended is unclear and, though the schools were designed as instruments of assimilation, their spread has been described as both tempered by Māori resistance and facilitated through Māori participation (Simon \& Smith, 2001; Smith, 2009). Violence, disease, abuse, and death have been well documented in residential schools in the U.S., Canada, and Australia (Jacobs, 2006; Milloy, 2017; TRC, 2015). The often-stated mission of these institutions was to destroy community and familial ties, traditional cultural practices, and Indigenous languages. For example, in Canada the explicit goal of residential schools was to "kill the Indian in the child" (TRC, 2015, p. 130).

In the second half of the $20^{\text {th }}$ century, States continued to separate Indigenous children from their families, communities, and cultures, but the mechanism shifted from schools to child welfare systems (Australian Law Reform Commission, 1997; Halverson et al., 2002; Milloy, 2017; Timpson, 1995). Recent literature suggests this history of State-sponsored removal of Indigenous children from their homes precipitated the present overrepresentation in the child welfare system in the four countries we are considering here (Sinha et al., 2013; Tilbury, 2009). In Canada, the residential school system began to phase out in the 1950s and 1960s and, during the same period, provincial child welfare systems began operating on reserve. Thousands of children were placed in out-of-home care by child welfare systems, often due to poverty and cultural misunderstanding, resulting in what is called the Sixties Scoop (Johnston, 1983; TRC, 2015). In the U.S., there was a similar mid-century shift toward placing Indigenous children with foster and adoptive families. U.S. Senate hearings in 1974 demonstrated deep biases in social service workers in removing Native American children from their homes, largely for reasons of neglect (Subcommittee on Indian Affairs, 1974). In Australia, Aboriginal children removed from their homes - the Stolen Generations - were placed in foster homes or adopted by White families (Australian Institute of Aboriginal and Torres Strait Islander Studies, 2018). Similarly, while a transition away from Native schools in New Zealand toward State-run child welfare systems began in the 1920s, throughout the mid-20 $0^{\text {th }}$ century Māori children were overrepresented in residential institutions (Dalley, 1998; Forbes \& Stevanon, 2017; United Nations Committee on the Elimination of Racial Discrimination, 2017).

Recent data from these countries indicate that Indigenous children continue to experience higher rates of involvement within child welfare systems than other children. In Canada, Indigenous children are less than $8 \%$ of the total child population but represent over $52 \%$ of the children in out-of-home care (Statistics Canada, 2018). In the United States, available data indicate that American Indian and Alaskan Native children represent less than $1 \%$ of all children but make up over $2 \%$ of out-of-home placements (National Indian Child Welfare Association, 2017). This disproportionality is compounded over time; it is estimated that more than $15 \%$ of Native American children, or 1 in 7 , will enter foster care before they turn 18, in contrast to less than $6 \%$ of all children in the United States (Wildeman \& Emanuel, 2014). In Australia, Indigenous children are less than $6 \%$ of the child population, yet represent $40 \%$ of the children in out-of-home care (Australian Institute of Family Studies, 2020). Additionally, one longitudinal study showed that over half of all Aboriginal or Torres Strait Islander children had contact with the child welfare system (Delfabbro et al., 2010). Finally, in New Zealand, Māori children represent 25\% of the child population, yet represent $55 \%$ of children in out-of-home child welfare placements (Children's Commissioner, 2016; Ministry of Social Development, 2017). 
The involvement of Indigenous children with child welfare systems is often driven by reports and investigations related to neglect. In Canada, cases involving child neglect are a primary driver of overrepresentation of Indigenous children and are linked to factors including poverty, poor housing, domestic violence, and substance use (Sinha \& Kozlowski, 2013; Sinha et al., 2011). Conditions associated with neglect link back to colonial histories of displacement and violence. Resulting economic disparities, intergenerational trauma, and differences in worldview can increase both the perception of neglect $^{6}$ and situations of actual harm (Caldwell \& Sinha, 2020; MacEachron \& Gustavsson, 2005; Swift, 1995). In the United States, American Indian and Alaskan Native children are more likely to be involved with child welfare systems for reasons of neglect than were other groups, and they are the least likely to be involved for reasons of physical abuse (Pew Charitable Trusts, 2007). Similarly, in Australia, emotional abuse and child neglect were the most frequent primary types of abuse and neglect experienced by Aboriginal and Torres Strait Islander children between 2017 and 2018. The high rates of neglect are consistent with the disadvantaged socioeconomic conditions prevalent in many Aboriginal and Torres Strait Islander communities, such as overcrowding, unemployment, and limited access to services (Steering Committee for the Review of Government Service Provision, 2014). Available data from New Zealand indicate a divergence from the pattern in the other countries. Among Māori children, the number of out-of-home placements for reasons of neglect is lower than for other maltreatment types (Oranga Tamariki, 2019). ${ }^{7}$

Present-day policy and governance structures in Canada, the United States, Australia, and New Zealand uniquely impact Indigenous families and children. In Canada, jurisdiction over Indigenous child welfare and family services is fraught with confusion between the federal and provincial governments, ${ }^{8}$ and has led to denial and underfunding of services for First Nation children, which was found to be a human rights violation by the Canadian Human Rights Tribunal. In the United States, federal legislation regulates Indigenous child welfare systems through the Indian Child Welfare Act (ICWA, 1978), which transfers legislative, administrative, and judicial decision-making to Indigenous communities when an on-reserve child is apprehended in the child welfare system. In Australia, federal and state governments share jurisdiction over Indigenous child welfare affairs, though each state or territory is responsible for developing and implementing Indigenous legislation and providing services. As a consequence, jurisdictional differences in Indigenous child welfare provisions have generated service disparities between places of residency (Paul, 2016). New Zealand, which has full federal jurisdiction over child protection issues, continues to face criticism for failures in considering Māori culture and community in

\footnotetext{
${ }^{6}$ For example, when multiple caregivers are in one household, a parent may not need to be as attentive, which could be seen through a Western child welfare lens as supervisory neglect (see for example Neckoway et al., 2007).

${ }^{7}$ We were not able to locate data on overall child welfare cases in New Zealand, but the data on children in care indicate a lower level of neglect cases compared to the other countries we examined. The divergence between available data for New Zealand and the other countries merits further study.

${ }^{8}$ Typically, provincial governments hold jurisdiction over child welfare in Canada. However, through Section 35 of the Constitution Act (1982), the federal government has jurisdiction over Indigenous Rights and Treaty Rights.
} 
child protection decisions. ${ }^{9}$

Systematically analyzing the variation in literature from across these four countries — which share similar settler colonial pasts but have divergent federal governance structures and policy realities - may be a valuable way to understand the variation related to Indigenous child welfare in each country. Similarities in governance structure across these four countries provide a foundation for cross-jurisdictional comparison of policies and practices impacting Indigenous families. However, there are important differences in each of these countries in terms of their approaches to balancing federal, state or provincial, and Indigenous governance to address the rights and unique needs of Indigenous children, families, and communities.

Given the comparable but uniquely situated histories, governance structures, and present-day patterns of removal of Indigenous children from their families in Canada, the United States, Australia, and New Zealand, the present scoping review gathers and analyzes available research on Indigenous involvement with child welfare systems in all four of these countries. We attempt to compile and examine research literature production over time and by critically examining the types and scope of literature, which arise (or are absent) from an academic search of literature. By synthesizing and comparing knowledge across and between jurisdictions, we hope to emphasize the potential for learning to both support implementation of new federal Indigenous child welfare policy in Canada and to inform further policy initiatives that improve outcomes for Indigenous families.

\section{Methods}

The following question guided this scoping review: "What is the state of literature on the topic of Indigenous child welfare involvement in Canada, the United States, Australia, and New Zealand?” Our objective was to draw attention to the broad scope of existing research on Indigenous child welfare. We also sought to better understand trends in research focus and type, as well as the gaps in available knowledge.

Based on Arksey and O’Malley's (2005) scoping review model, which Levac et al. (2010) further developed, we undertook a process of identifying, charting, and summarizing existing research related to our research question. Multiple authors who have completed recent reviews of Indigenous child welfare or child welfare related literature (e.g., Fiolet et al., 2019; Gatwiri et al., 2019; Haight et al., 2018; Macvean et al., 2017) that are narrowly focused on empirical literature have noted the dearth of Indigenous voices and perspectives. Accordingly, we kept our inclusion parameters wide, purposely seeking to include studies that might be excluded if we applied selection criteria that focused narrowly on methodology or research design. Growing attention to Indigenous ways of knowing and research methodology are increasingly challenging classifications such as empirical and non-empirical that have long been central to the dominant, Western academic framework. Though we do use these terms in organizing our search results, we do so recognizing that they risk perpetuating a paradigm that may not reflect the worldviews of Indigenous families and children that are the focus of this literature.

\footnotetext{
${ }^{9}$ The Children, Young Persons and their Families Act (1989) articulated considerations of how child welfare decisions impact Indigenous children. However, its application has been limited due to oversight and funding concerns (Libesman, 2014).
} 
We limited our search to literature pieces published between 1973 - the beginning of the period for which our electronic search yielded consistent, annual results - and 2018. The inclusion of several decades of literature was intended to allow for the examination of trends over time, and to span the period in which the disproportionate involvement of Indigenous children in all four countries emerged. Our scoping review process is outlined in Figure 1.

\section{Figure 1. Scoping Review Process}

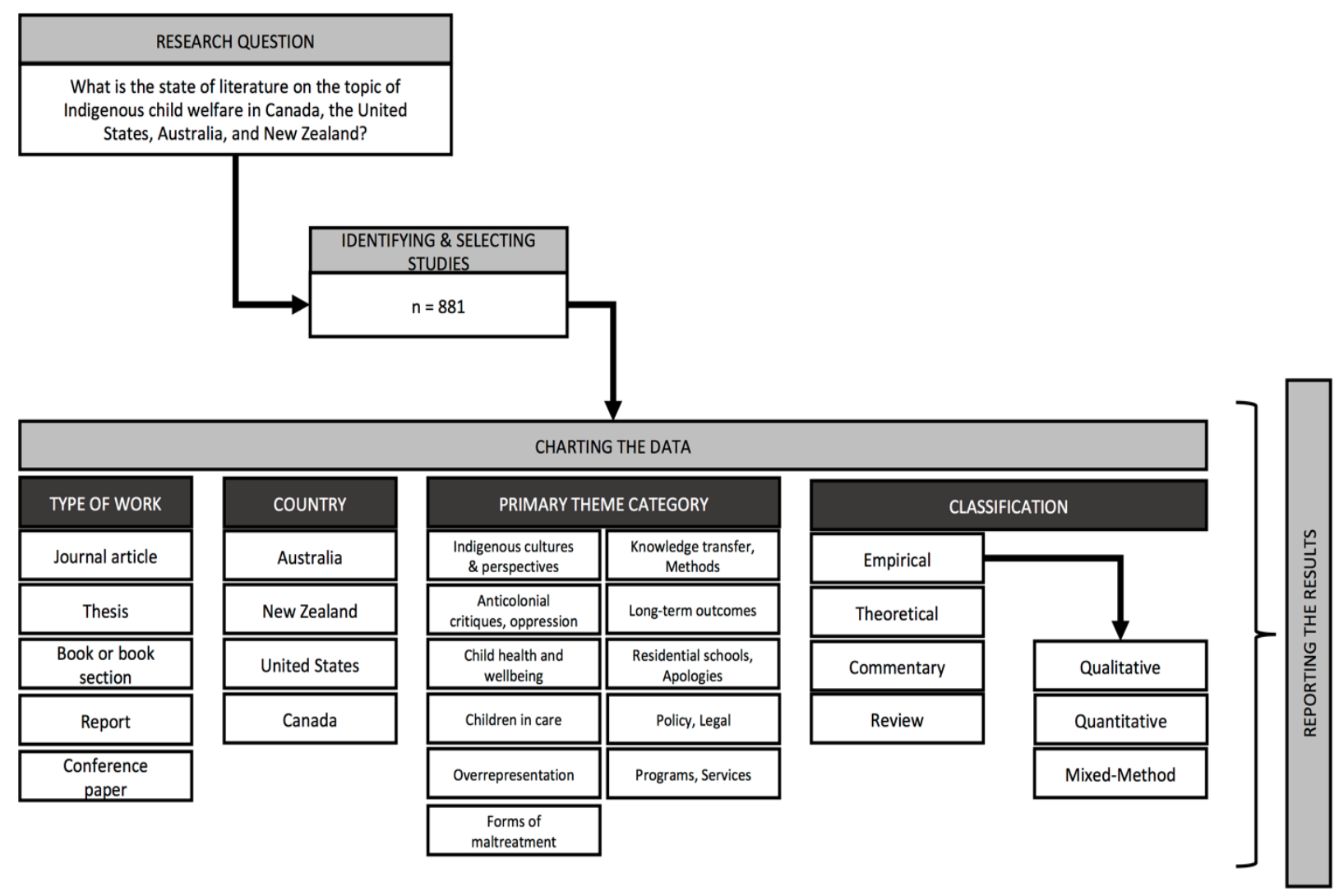

Our literature identification process involved searches in several social science electronic databases: ASSIA (Applied Social Sciences Index and Abstracts), MEDLINE, Social Service Abstracts, SocINDEX with Full Text, Social Work Abstracts, PsycINFO, and WorldCat (McGill University). We used two sets of keywords in our searches, summarized in Table 1. Our interest was in gathering the fullest possible set of literature produced over a long historical period; therefore, the first list included legacy search terms that may have been used in older sources but are now considered pejorative. The first and second sets of keywords were searched using the Boolean operators "OR" between words within each set and "AND" to combine sets.

After reviewing articles resulting from our searches, we included literature specifically pertaining to Indigenous child welfare and excluded research focusing only on Indigenous mental health, education, addiction, or other topics. Only articles published in English were considered due to our research team's 
The International Indigenous Policy Journal, Vol. 12, Iss. 1

linguistic capacity. After verification among members of our team, we included a total of 881 literature pieces for descriptive analysis in the scoping review.

To document the literature found in our search, we created a database using Microsoft Excel to capture information about the included pieces. In addition to a citation and summary of each article, we included the following information in our database: type of work (journal article, thesis, book or book section, report, and conference paper); country (Canada, U.S., Australia, NZ, or multiple countries); primary theme; literature classification (empirical or non-empirical); empirical study design (if applicable); and empirical study details (if applicable).

Table 1. Keyword Searches

\begin{tabular}{|c|c|}
\hline First set of keywords & Second set of keywords \\
\hline $\begin{array}{c}\text { Aboriginal, "First Nations," "Native American,” } \\
\text { Inuit, Métis, “Torres Island," “Torres Strait } \\
\text { Islander," Māori, Eskimo, "Canadian Eskimo," } \\
\text { Aborigines, "Indians of North America," “Arctic } \\
\text { Peoples," "North American Indians," "American } \\
\text { Native," "American Indian,” Indigenes, and } \\
\text { Indians }\end{array}$ & 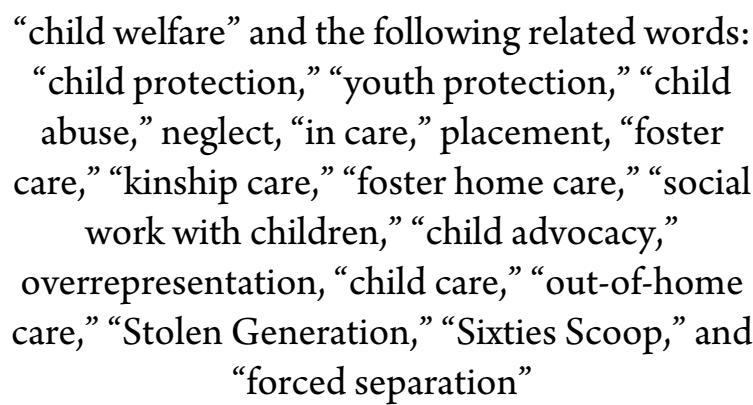 \\
\hline
\end{tabular}

As we reviewed the research publications, we identified themes through applied thematic analysis (e.g., Guest et al., 2011; see Figure 1). We conducted this iterative coding process through review of the abstracts, discussion among our team members about possible themes, and reassessment of some initially identified themes, which we collapsed due to low article counts or for the sake of conceptual clarity. For example, we originally coded child health trajectories and child wellbeing separately, but we decided to combine them as child health and wellbeing due to low numbers in each and the significant conceptual overlap between the two codes. This process yielded the following list of 11 primary themes: Indigenous cultures and perspectives; programs, services; anti-colonial critiques and oppression; child health and wellbeing; knowledge transfer and methods; children in care; overrepresentation; policy and legal; forms of maltreatment; long-term outcomes, and residential schools and apologies. While the majority of articles were related to more than one theme (e.g., children in care and child health and wellbeing), we opted to assign each research publication a primary theme. One reviewer on our team assigned a primary code to each, and then a second team member re-coded some of the articles to establish consistency across the coding process.

In our review of the classification of research publications, we initially coded them as empirical, theoretical, commentary, or review. The latter three classifications were considered non-empirical: articles classified as theoretical built on existing research and theory to extensively critique, significantly 
extend, or reimagine existing theory; commentary pieces drew from existing knowledge and personal and/or professional experiences; and review publications summarized, synthesized, and commented on pre-existing empirical research, theoretical writing, or commentaries. These review pieces tended to propose important questions and areas for future research but did not extend the existing knowledge base by contributing new analyses of primary data. By contrast, empirical pieces presented original analyses of data and were sub-categorized as quantitative, qualitative, or mixed method. We included empirical study details in our database with further details on population, methods, and findings.

\section{Findings}

Our search of Indigenous child welfare literature yielded 880 unique publications produced in Canada, the United States, Australia, and New Zealand between January 1973 and April 2018. We analyzed this literature according to time, geography, and empirical classification. Table 2 presents an overview of literature resulting from our search, which we analyze in more granular detail below.

Table 2. Type of Literature by Country (January 1973 to April 2018)

\begin{tabular}{|c|c|c|c|c|c|c|}
\hline & \multicolumn{4}{|c|}{ Empirical } & \multirow{2}{*}{$\begin{array}{c}\text { Non-empirical } \\
\text { Total }\end{array}$} & \multirow[b]{2}{*}{$\begin{array}{c}\text { Country } \\
n\end{array}$} \\
\hline & Qualitative & Quantitative & $\begin{array}{c}\text { Mixed } \\
\text { methods }\end{array}$ & Total & & \\
\hline Canada & 77 & 55 & 15 & 147 & 160 & 307 \\
\hline United States & 51 & 86 & 25 & 162 & 156 & 318 \\
\hline Australia & 43 & 32 & 15 & 90 & 99 & 189 \\
\hline New Zealand & 6 & 9 & 1 & 16 & 24 & 40 \\
\hline $\begin{array}{l}\text { Multiple } \\
\text { countries }\end{array}$ & 2 & 2 & 0 & 4 & 23 & 27 \\
\hline Category $n$ & 179 & 184 & 56 & 419 & 462 & 881 \\
\hline
\end{tabular}

Note. $N=881$.

\section{Total Breakdown by Country}

Of the total of 881 research publications produced between January 1973 and April 2018, we found 307 articles focusing on Indigenous child welfare in Canada, 318 for the United States, 189 for Australia, and 40 for New Zealand. In addition, there were 27 articles that focused on Indigenous child welfare in more than one country. Over time, the number of total publications per year increased. Figure 2 illustrates these results, covering the period from January 1995 to December $2017,{ }^{10}$ during which time $87 \%$ $(n=767)$ of all publications we found were published. In the last decade in particular, we noted a higher

\footnotetext{
${ }^{10}$ For graphical clarity purposes, we excluded pre-1995 counts, when no more than 10 research pieces were produced in any given year. We also excluded 2018 from the figure because the data accounted for only four months (January through April) of that year.
} 
number of publications, with significant peaks in 2009 and 2014. Since 2014, literature production has more or less stabilized at about 71 works per year across these four countries, although the literature is not evenly distributed across them.

Figure 2. Literature Counts by Year and Country of Focus (1995-2017)

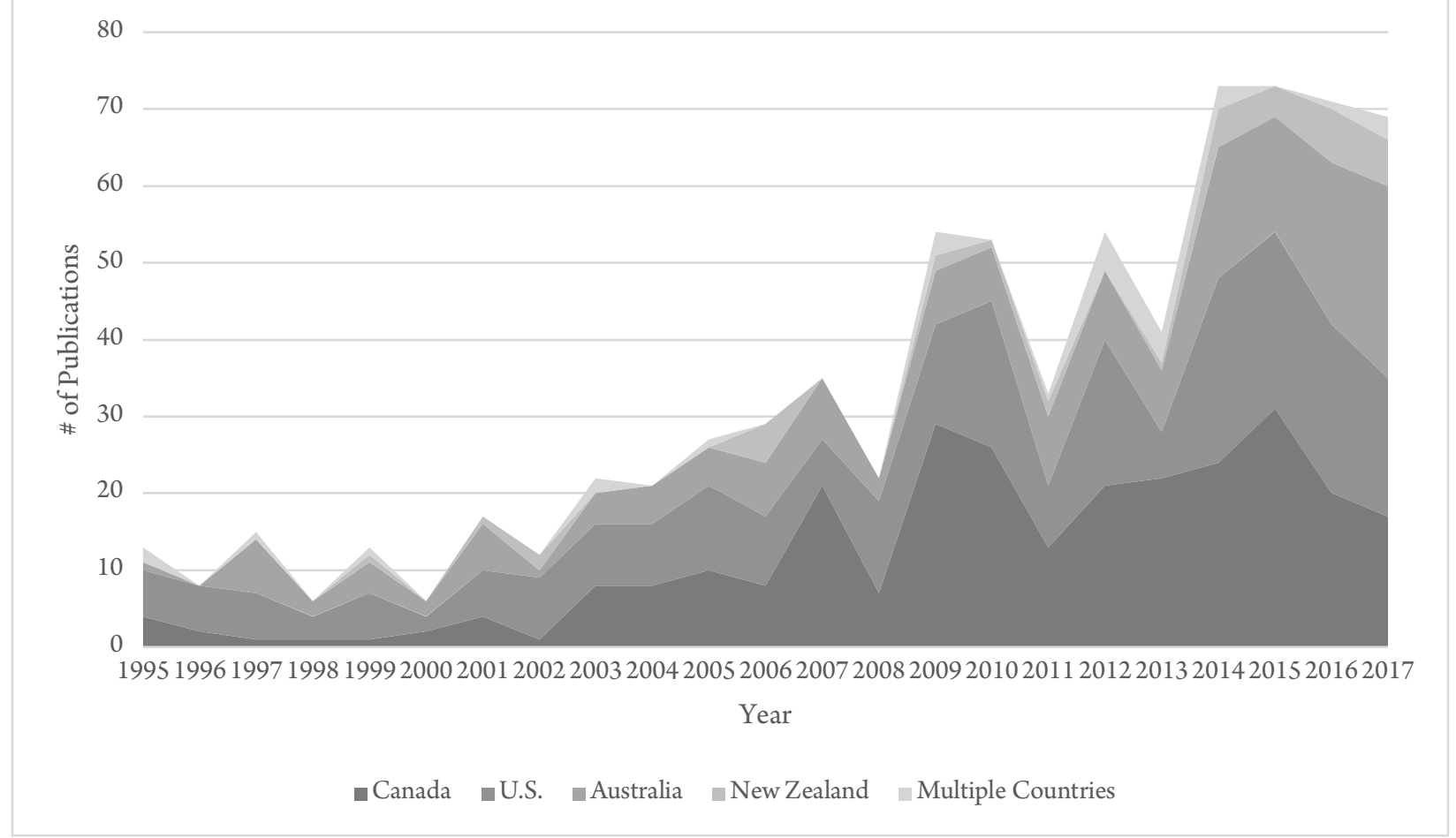

\section{Trends Over Time by Country}

As shown in Figure 2, the quantity of Indigenous child welfare literature focusing on Canada, the United States, and Australia has rapidly increased, with a smaller increase in literature focusing on the New Zealand context. The expansion of child welfare research focused on Canada, the U.S., and Australia, parallels legal and policy developments that drew media attention to Indigenous child welfare in the public sphere. In Canada, the national Truth and Reconciliation Commission of Canada included extensive public testimony from Indigenous people and an inquiry into painful histories of residential schools (TRC, 2015). A Canadian Human Rights Tribunal case, initiated in 2007 and continued through 2016, focused on discrimination against First Nations children in child welfare and has prompted further remedial action (Blackstock, 2016; First Nations Child and Family Caring Society, 2020b). In addition, the First Nations Component of the Canadian Incidence Study of Reported Child Abuse and Neglect (FNCIS-2008), the first full-scale national study of First Nations children in the child welfare system released findings demonstrating overrepresentation in 2011 (Sinha et al., 2011).

Similarly, in the U.S., increases are likely associated with greater media attention surrounding the 
overrepresentation of Indigenous children in the U.S. foster care system. For instance, since 2011, the National Council of Juvenile and Family Courts Judges has published annual briefs emphasizing this disproportionality (e.g., Padilla \& Summers, 2011; Summers et al., 2013). In addition, highly publicized national-level court cases $^{11}$ that were linked to the ICWA may have also prompted further publication.

In Australia, Indigenous child welfare research production also increased beginning in 2009. Similar to public reports in Canada and the U.S., a report in Australia on the separation of Aboriginal and Torres Islander children from their families highlighted the overrepresentation of Indigenous families and youth in the Australian child welfare system (HREOC, 1997). The year 2017 marked 20 years since the publication of this report, which highlighted human rights violations against Indigenous families and articulated Calls to Action to redress them. A number of media pieces from this same year also noted that little had changed for Indigenous families since the report was published (Brown, 2017; Conifer, 2017; Dabbagh, 2017; Wahlquist, 2017), reflecting increased public attention to this issue. In New Zealand, there was a consistently smaller number of publications overall compared to the number of publications in other countries at which we looked. However, the amount of literature focusing on New Zealand has increased slightly since 2014. This uptick in publications seems to align with legislative reforms and federal government restructuring (Keddell, 2017) ${ }^{12}$ that have been widely critiqued as deprioritizing the role of Māori conceptions of family and increasing liability-focused child welfare assessment practices (Hyslop, 2017).

\section{Total Empirical and Non-Empirical Publications}

We found a balance among empirical and non-empirical publications when looking at the total number of publications between 1973 and 2018. Empirical publications presented original analyses of data, while non-empirical publications were either theoretical, commentary, or review pieces. Overall, we classified $47.5 \%(n=419)$ of the literature reviewed as empirical and $52.5 \%(n=462)$ non-empirical. This balance held across countries: Our search yielded around 50\% empirical and 50\% non-empirical for each country.

\section{Empirical and Non-Empirical Publications Over Time}

Over time, however, we noted a shift from a higher proportion of empirical publications toward more non-empirical publications. Figure 3 presents the quantity of empirical and non-empirical literature that

\footnotetext{
${ }^{11}$ For example, Adoptive Couple v. Baby Girl (2013), which questioned the applicability of the ICWA, was heard by the U.S. Supreme Court in 2013. That same year, the American Civil Liberties Union (ACLU) filed a federal court lawsuit on behalf of the Oglala Sioux and the Rosebud Sioux tribes against the state of South Dakota for not complying with the ICWA.

${ }^{12}$ In the mid-2010s, there were a number of reforms to federal legislation regarding child welfare. In April of 2017, a new Ministry for Vulnerable Children, Oranga Tamariki, replaced the federal agency of Children, Youth, and Families. The new ministry added preventive services and services for young people in care transitioning to adulthood to its mandate, among others (Keddell, 2017). In 2017, two federal legislative amendments-the Vulnerable Children Amendment Act (2014) and the Children, Young People, and Their Families (Oranga Tamariki) Legislation Act (1989) — adapted existing child welfare laws to be more child-focused and attentive to context.
} 
was produced between January $19955^{13}$ and December $2017 .{ }^{14}$ As illustrated in Figure 3, prior to 2007, the number of non-empirical research publications generally surpassed the quantity of empirical literature. Since 2007, empirical literature production has steadily increased at a similar rate to that of non-empirical research. However, in 2017 , the empirical literature quantity was more than double that of non-empirical

Figure 3. Counts of Empirical and Non-Empirical Literature by Year (1995-2017)

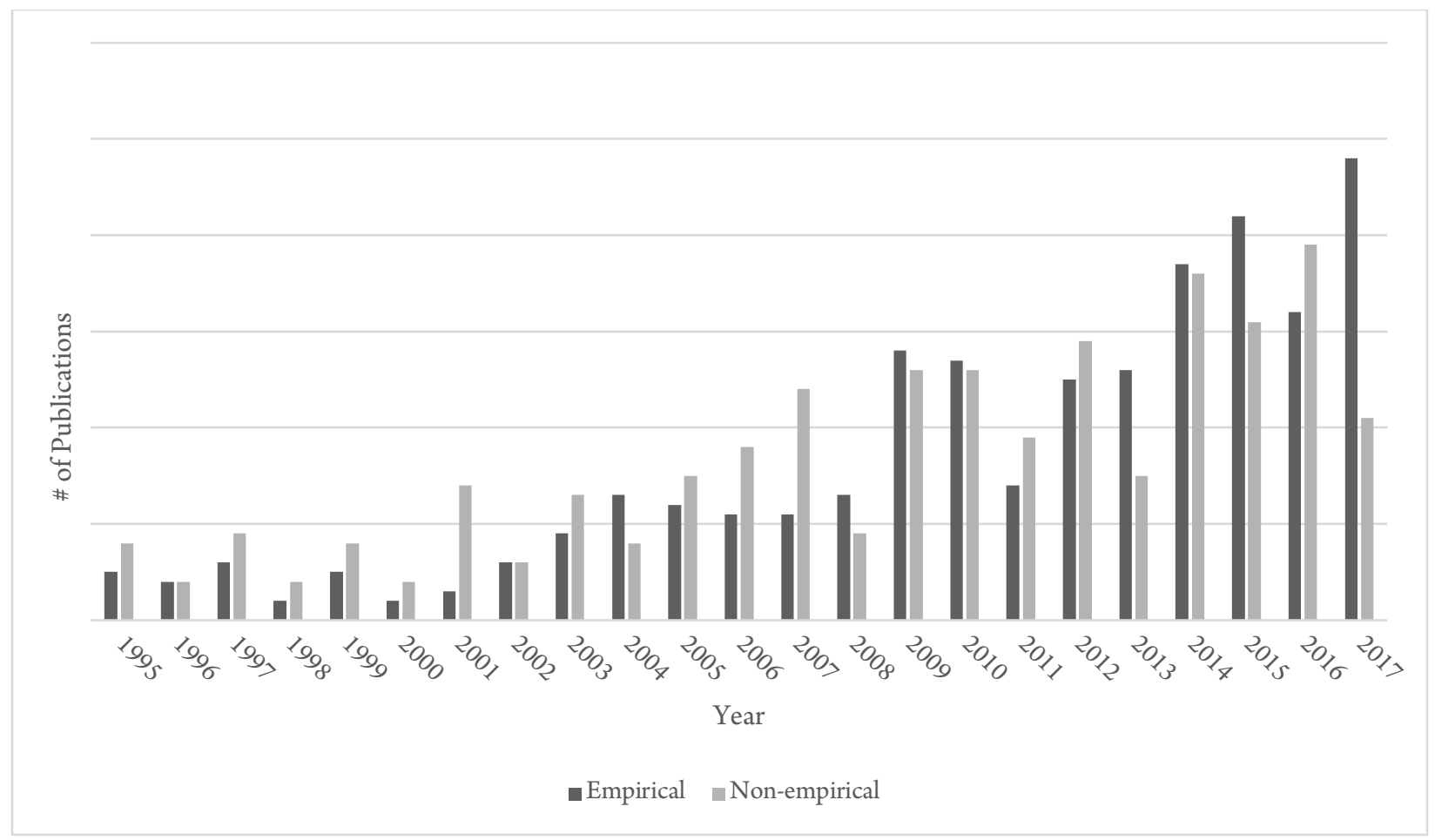

\section{Empirical and Non-Empirical by Country}

We further broke down empirical pieces according to research method (either qualitative, quantitative, or mixed methods; see Figure 4); there is no clear trend over time.

\footnotetext{
${ }^{13}$ For graphical clarity, we excluded pre-1995 counts, when no more than 10 research publications were produced in a given year.

${ }^{14} 2018$ was eliminated because the entire year was not captured in our review.
} 
Figure 4. Percentage of Empirical Publications by Research Method Over Time (1995-2017)

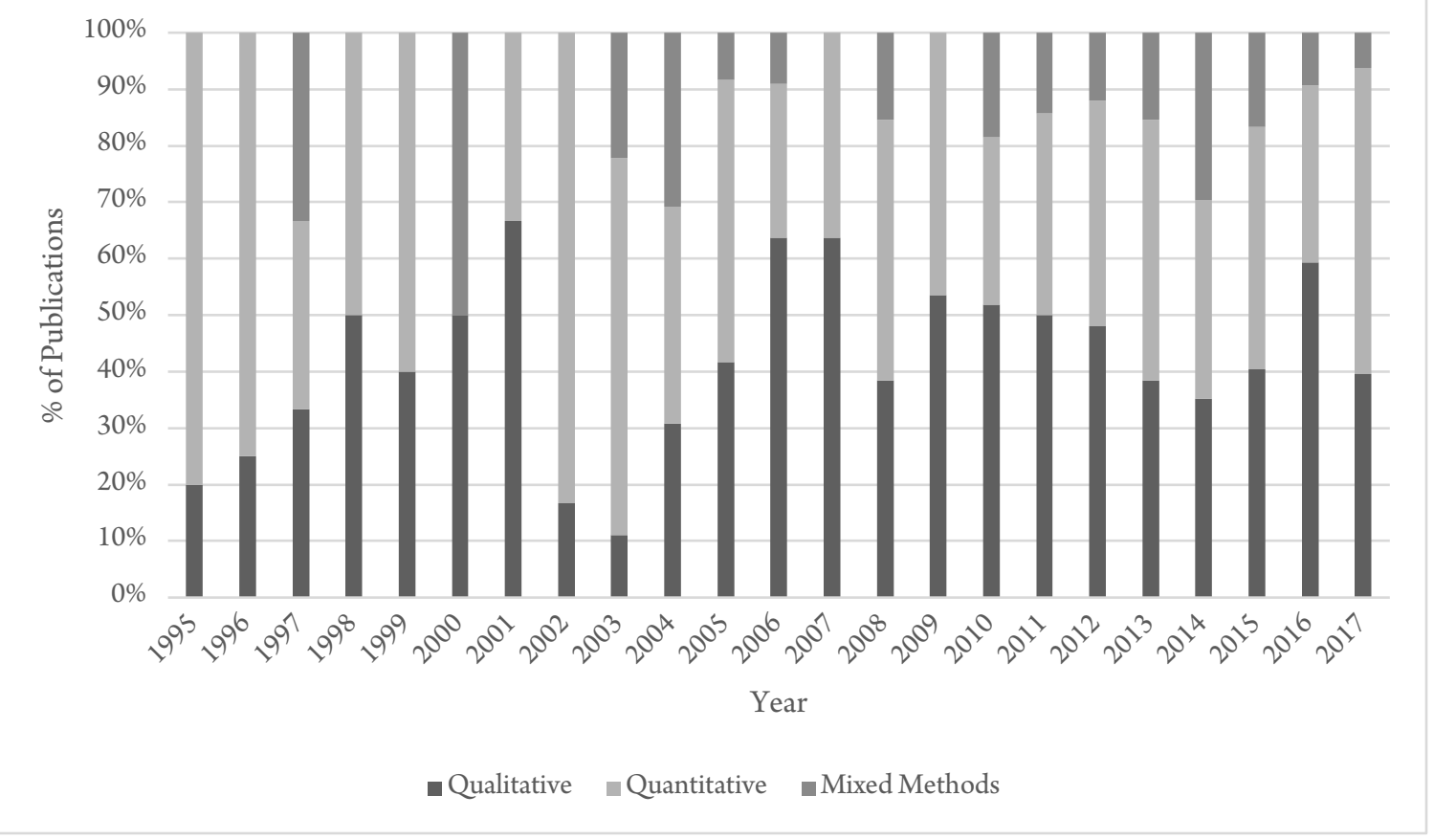

\section{Thematic Coding Findings}

Table 3 provides a full summary of the results according to primary theme, empirical nature, and type of empirical study. We broke the classification of pieces down according to our thematic coding. Themes that had the largest number of research pieces were programs and services $(n=191)$, policy and legal $(n=168)$, and overrepresentation $(n=104)$. Conversely, the themes with the lowest number of pieces were Indigenous cultures and perspectives $(n=37)$, knowledge transfer, methods $(n=34)$, and forms of maltreatment $(n=22)$.

The following are core findings from the literature that are extracted from each of the 11 scoping review themes. 
Table 3. Descriptive Results, Indigenous Child Welfare Research Publications from Canada, the United States, Australia, and New Zealand, January 1973 to April 2018

\begin{tabular}{|c|c|c|c|c|c|c|}
\hline \multirow[b]{2}{*}{ Themes or codes } & \multirow[b]{2}{*}{$\begin{array}{c}\text { Total } \\
\text { literature }\end{array}$} & \multirow{2}{*}{$\begin{array}{c}\text { Total } \\
\text { non- } \\
\text { empirical }\end{array}$} & \multirow[b]{2}{*}{$\begin{array}{c}\text { Total } \\
\text { empirical }\end{array}$} & \multicolumn{3}{|c|}{ Type of empirical, \% } \\
\hline & & & & Qualitative & Quantitative & $\begin{array}{l}\text { Mixed } \\
\text { Methods }\end{array}$ \\
\hline Programs and services & 191 & 90 & 101 & $61 \%$ & $19 \%$ & $20 \%$ \\
\hline Policy and legal & 168 & 135 & 33 & $70 \%$ & $12 \%$ & $18 \%$ \\
\hline Overrepresentation & 104 & 25 & 79 & $6 \%$ & $89 \%$ & $5 \%$ \\
\hline $\begin{array}{l}\text { Anticolonial critiques } \\
\text { and oppression }\end{array}$ & 89 & 77 & 12 & $67 \%$ & $17 \%$ & $17 \%$ \\
\hline Children in care & 87 & 23 & 64 & $50 \%$ & $39 \%$ & $11 \%$ \\
\hline $\begin{array}{l}\text { Residential schools } \\
\text { and apologies }\end{array}$ & 53 & 33 & 20 & $60 \%$ & $35 \%$ & $5 \%$ \\
\hline $\begin{array}{l}\text { Child health and } \\
\text { wellbeing }\end{array}$ & 52 & 26 & 26 & $27 \%$ & $50 \%$ & $23 \%$ \\
\hline Long-term outcomes & 44 & 6 & 38 & $5 \%$ & $79 \%$ & $16 \%$ \\
\hline $\begin{array}{l}\text { Indigenous cultures } \\
\text { and perspectives }\end{array}$ & 37 & 20 & 17 & $82 \%$ & $18 \%$ & $0 \%$ \\
\hline $\begin{array}{l}\text { Knowledge transfer } \\
\text { and methods }\end{array}$ & 34 & 20 & 14 & $57 \%$ & $29 \%$ & $14 \%$ \\
\hline $\begin{array}{l}\text { Forms of } \\
\text { maltreatment }\end{array}$ & 22 & 7 & 15 & $40 \%$ & $47 \%$ & $13 \%$ \\
\hline Total & 881 & 462 & 419 & $43 \%$ & $44 \%$ & $13 \%$ \\
\hline
\end{tabular}




\section{Programs and services}

The literature in this category describes and evaluates Indigenous child welfare services and programs. Literature in this domain highlights promising and best practices including culturally competent care (Bessarab \& Crawford, 2010; Red Horse, 1982; Sinclair, 2008; Weaver, 1999), and relationship building between the worker and the family (Hughes et al., 2016; Kreitzer \& Lafrance, 2010; McAuliffe et al., 2016; Sommerlad, 1977). It describes specific approaches, such as family group conferencing in which the social worker and child's family and community unite to determine how to keep the child safe (Connolly \& MacKenzie, 1998; Ney et al., 2013; Schmid \& Pollack, 2004; Waites et al., 2004). It also details intervention models developed and implemented by Indigenous community workers including interventions focusing on family preservation, fetal alcohol syndrome, and substance abuse (Cripps \& McGlade, 2008; Howard-Wagner, 2015; McKenzie, 1989; Myhra et al., 2015). There are also recommendations for a social work education reform, including appeals for more cultural-competency training (Harms et al., 2011; Strega \& Esquao, 2015; Zufferey et al., 2015).

\section{Policy and legal}

The literature included in this category examines specific legislation, court cases, and policies related to Indigenous involvement in child welfare. One focus is on past and current governmental policies that have shown to assimilate and marginalize Indigenous Peoples (Armitage, 1995; D’Souza, 1994; MacDonald \& Ladd, 2000). Also included are analyses of governmental policies that were introduced to address the overrepresentation of Indigenous children in child welfare and service discrepancies between on- and off-reserve communities (Cradock, 2007; Hudson \& McKenzie, 2003; Wien et al., 2007). Some of the literature also addresses the Canadian Human Rights Tribunal (Blackstock, 2009, 2011 a, 2011b), Jordan's Principle in Canada ${ }^{15}$ (King, 2012; Lett, 2008; MacDonald \& Attaran, 2007), and the U.S. Indigenous Child Welfare Act (Akhtar, 2012; Bending, 1997; Deitrich, 1982; Yablon, 2004). Literature in this primary theme also contains critiques of the neoliberal child welfare model, which is framed as reactive, bureaucratic, and managerial, resulting in greater policing of families (Hackell, 2016; Hyslop, 2017; Keddell, 2017; Libesman, 2015). Alternative child welfare frameworks, such as a human rights framework, are proposed to be more collaborative with families in practice (Filipetti, 2016; Libesman, 2015) and are suggested as a way to "re-establish to the greatest extent possible individuality and sovereignty within each Indigenous community” (Paul, 2016, p. 188).

\section{Overrepresentation}

The literature in this category includes analyses of child welfare population-based datasets, which consistently document the overrepresentation of Indigenous youth in child welfare systems in the United States (Collmeyer, 1995; Crofoot \& Harris, 2012; Mech, 1983), Canada (Blackstock et al., 2004; Sinha et al., 2011; Trocmé et al., 2003), Australia (Delfabbro et al., 2010; Tilbury, 2009; Zhou \& Chilvers, 2010), and New Zealand (Buchanan \& Malcolm, 2010; Cram et al., 2015). In addition, there is a disproportionate number of Indigenous families who are reported to and investigated by child welfare

\footnotetext{
${ }^{15}$ Jordan's Principle was conceived in response to a jurisdictional dispute over who would pay for First Nations child Jordan River Anderson's home care. The principle is meant to ensure that Indigenous children's needs are put first when they come in contact with health and social service systems and that provincial and federal governments reconcile costs post facto if needed (The Jordan's Principle Working Group, 2015).
}

Published by Scholarship@Western, 2021 
officials (Bailey et al., 2015; Collings et al., 2018; Sinha et al., 2013). The major correlate for this overrepresentation is parental neglect, which is often associated with poverty, inadequate housing, mental illness, and substance addiction (Lujan et al., 1989; White \& Cornely, 1981). Additionally, the overrepresentation can be linked to a lack of culturally appropriate services and cultural biases that can put Indigenous parents at higher risk of scrutiny (Dumont, 1988; Hélie et al., 2013; Hill, 2008).

\section{Children in Care}

The literature included in this category examines kinship care, foster care, and adoption practices, as well as the treatment and experiences of Indigenous youth in care. Kinship care, which is generally provided by grandparents, is often the optimal choice for Indigenous children in care (Hill, 2016; Spence, 2004; Worrall, 2006). Although kinship care is challenging, it has been underfunded and under-resourced (Hill, 2016; Mutchler et al., 2007; Purcal et al., 2014; Worrall, 2006). Additionally, there is a shortage of Indigenous foster parents, despite there being an overrepresentation of Indigenous children in the child welfare system, which has been attributed to a mistrust of social workers and traumatic child welfare experiences (Brown et al., 2010; Halverson et al., 2002; Hanna et al., 2017). The literature suggests detrimental effects from placing Indigenous children in White foster homes, especially because children who are disconnected from their Indigenous culture and community tend to have difficulty developing a positive self-identity (Becker-Green, 2009; Moss, 2009; Sinclair, 2008). Additionally, publications in this theme document discrimination, oppression, and inequities that Indigenous youth in care experience (Anderson, 2014; Berlin, 1978; Green, 1983). Research calls for "culturally appropriate care," which includes cultural connectivity plans with Indigenous families and youth in care (Anderson, 2014; Green, 1983; Klamn, 2009; Raman et al., 2017).

\section{Anticolonial Critiques and Oppression}

The literature included in this category focuses on the impacts of colonialism on Indigenous families and children. Some of this literature frames recent policies resulting in mass removal of Indigenous children from their families and communities as an extension of the cultural genocide enacted against Indigenous people through settler colonial policies and practices (Cross \& Blackstock, 2012; Cunneen \& Libesman, 2000; O'Connor, 1994; Richardson \& Nelson, 2007). Discourse justifying the persistent state intervention in Indigenous communities include "for their own good" rhetoric and the importance of civilizing the "savage" and "deviant" "Native" (de Leeuw et al., 2010, p. 286; Landertinger, 2016, p. 1; Palmer \& Cooke, 1996, p. 710). In addition, the literature comments on the neoliberal child welfare system that led to greater austerity, privatization of services, and bureaucracy, which is described as ultimately furthering inequities between Indigenous and non-Indigenous children and families (Cunneen, 2015; Haebich, 2016; Kennedy-Kish et al., 2017; Rousseau, 2015). This literature also touches on historical and intergenerational trauma resulting from the systematic oppression of Indigenous Peoples under both colonial and neoliberal policies (Burnette \& Figley, 2016; Maxwell, 2014; Moorehead \& LaFromboise, 2014; Sherwood, 2015).

\section{Residential Schools and Apologies}

The literature included in this category describes residential school experiences in Canada, the U.S., Australia, and New Zealand, as well as government attempts to facilitate reconciliation in the wake of growing recognition of the harms and ongoing intergenerational impacts of these schools and their roles 
in furthering cultural genocide (Chadwick et al., 1986; Jacobs, 2014; Stephenson, 2006; van Krieken, 1999a, 1999b). The literature details assimilation tactics employed to extinguish Indigenous culture, as well as the child sexual and physical abuse that occurred within the school (Burich, 2007; Kuipers, 2015; Matheson et al., 2016). It documents ongoing psychiatric problems that some residential school survivors continue to experience, including substance addiction, gambling addiction, depression, posttraumatic stress disorder, and intergenerational trauma (Beiser, 1974; Bombay et al., 2013; Cromer et al., 2017; Reed, 2010; Ross et al., 2015). Government-led investigations to determine the extent of harm as a result of the residential schools and reports detailing reconciliation processes occurred in the late $20^{\text {th }}$ and early $21^{\text {st }}$ centuries in Canada and Australia (Attean et al., 2012; HREOC, 1997; Wilson, 2015). A number of scholars have critiqued Australia's reconciliation process, which began more than 20 years ago, as most of the calls to action have yet to be actualized (Davis, 2017; Fejo-King, 2011; Fernandez et al., 2017).

\section{Child Health and Wellbeing}

The literature in this category examines inequities in health and social services and disparities in health outcomes for Indigenous children, making links to child maltreatment and/or the child welfare system. It highlights a profound lack of culturally appropriate services for Indigenous families, focusing on Indigenous populations living on reserve in particular (Canadian UNICEF Committee, 2009; Joshua et al., 2015; Liu \& Alameda, 2011). Service inequities augment the health and wellbeing challenges within Indigenous communities, where higher rates of youth suicides and family maltreatment, compared to non-Indigenous communities, have significant and long-lasting multigenerational impacts both for families and communities (Berlin, 1987; Kenney \& Singh, 2016; Wallace, 1973). Intervention models to promote Indigenous child health and wellbeing are provided and a persistent recommendation is that greater connection to Indigenous traditions and cultures is linked with better health outcomes (Carriere, 2005; Freeman et al., 2016; McShane, 1988; Priest et al., 2012).

\section{Long-Term Outcomes}

The literature included in this category assesses trajectories and outcomes related to child maltreatment in Indigenous communities. Wide-ranging negative impacts on youth and adults are described. Child maltreatment and foster care experiences have been associated with offending youth behaviors, teen pregnancy, and youth homelessness (Barker et al., 2014; Malvaso et al., 2017; Nordberg et al., 2014; Shah et al., 2017). A significant finding is the correlation of adult psychiatric symptomology and experiences of childhood abuse and/or neglect. Specifically, several studies have demonstrated that Indigenous adults with child maltreatment histories also had a greater chance of experiencing posttraumatic disorder, depression, substance addictions, and suicidality (Barker-Collo, 1999; Mota et al., 2012; Piasecki et al., 1989).

\section{Indigenous Cultures and Perspectives}

The literature included in this category describes culturally based Indigenous childrearing, as well as tensions between Western and Indigenous views on parenting, attachment, and maltreatment. This literature explores the impact of colonization and assimilation policies on Indigenous childrearing (Glover, 2001; Moffat, 1994; Neckoway, 2011; Pihama et al., 2016). It also examines Indigenous definitions of "family" as including extended family and community networks, contrasting with 
traditional Western understandings of family that are more likely to emphasize nuclear families (Cross, 2014; Limb et al., 2008; Montgomery-Andersen \& Borup, 2012). Some works in this category critique the application of Western-based attachment theory in child welfare work with Indigenous families, positing that it unfairly discredits Indigenous parenting paradigms (Lindstrom \& Choate, 2016; Neckoway et al., 2003; Yeo, 2003).

\section{Knowledge Transfer and Methods}

The literature in this category explores patterns and gaps in Indigenous child welfare research, research methodologies, and dissemination strategies. Several publications maintain that more empirical evidence-based research is needed in the field of Indigenous child welfare (e.g., Bennett et al., 2005; Timpson, 1995; Wells et al., 2009) and note the shortage and shortcomings of existing, populationbased child welfare data (Fraser, 2013; Tilbury \& Thoburn, 2009; Tonmyr et al., 2009). A number of publications advocate employing research methods, such as participatory action research, that center Indigenous voices and experiences (McKenzie, 1997; Poupart et al., 2009; Timpson, 2010; Waechter et al., 2009). Strategies for Indigenous child welfare research dissemination are also highlighted (Bennett, 2007; de Finney et al., 2009; Green et al., 2010; Leung et al., 2011). Literature in this category also comments on the propagation of negative Indigenous stereotypes and a lack of structural oppression analysis in recent Indigenous child welfare reporting (Harding, 2009; Lonne \& Gillespie, 2014; Maydell, 2018).

\section{Forms of Maltreatment}

The literature in this category includes research focusing on specific types and subcategories of child maltreatment and neglect in Indigenous populations. The majority of the articles focus on sexual abuse or neglect. The neglect-focused articles explore associated risk factors, articulate divergent perceptions and definitions of neglect, and examine implications for Indigenous children (Evans-Campbell, 2008; Nelson et al., 1996; Newton, 2017; Slee, 2001). The research focusing on sexual abuse covers topics such as the correlates of sexual abuse, divergent perceptions and experiences of disclosing sexual abuse, the ways in which both communities and legal institutions silence and marginalize victims, and a lack of appropriate services in Indigenous communities (Bailey et al., 2015; Hamilton et al., 2016; Hodgson, 1990; Smallwood, 1995; Stanley et al., 2003). A handful of articles also focus on more specific topics such as maltreatment related injury (O’Donnell et al., 2010; Pike \& First Nations and Inuit Child and Youth Injury Indicators Working Group, 2011).

\section{Empirical Literature by Theme}

We further classified the research publications as empirical (publications that present methodological details to describe the approach to new analyses of quantitative and/or qualitative data) and nonempirical (reviews, commentaries, theoretical pieces, and information-memoranda). Most empirical research was categorized under the themes programs and services $(n=101$ research publications), overrepresentation $(n=79)$, and children in care $(n=64)$. Six themes hold comparable proportions within the total and empirical literature. For example, child health and wellbeing research encompasses 
both $6 \%$ of the total literature and $6 \%$ of empirical research publications. ${ }^{16}$ However, five themes hold dissimilar portions in the total and empirical literature. For instance, policy and legal makes up 19\% of total literature in our review but represents only $11 \%$ of empirical research. This difference reflects the relatively large number of theoretical or conceptual discussion pieces included in this category. Another noteworthy example is the quantity of overrepresentation research within total (12\%) and empirical (19\%) literature. ${ }^{17}$ The greater proportion within empirical literature may be a result of a number of large-scale quantitative studies, such as the FNCIS-2008, which document the overrepresentation of Indigenous children in child welfare systems. Figure 5 illustrates the breakdown of empirical research methods by primary theme.

Figure 5. Empirical Research Methods by Primary Theme (Canada, the United States, Australia, and New Zealand, 1973-2018)

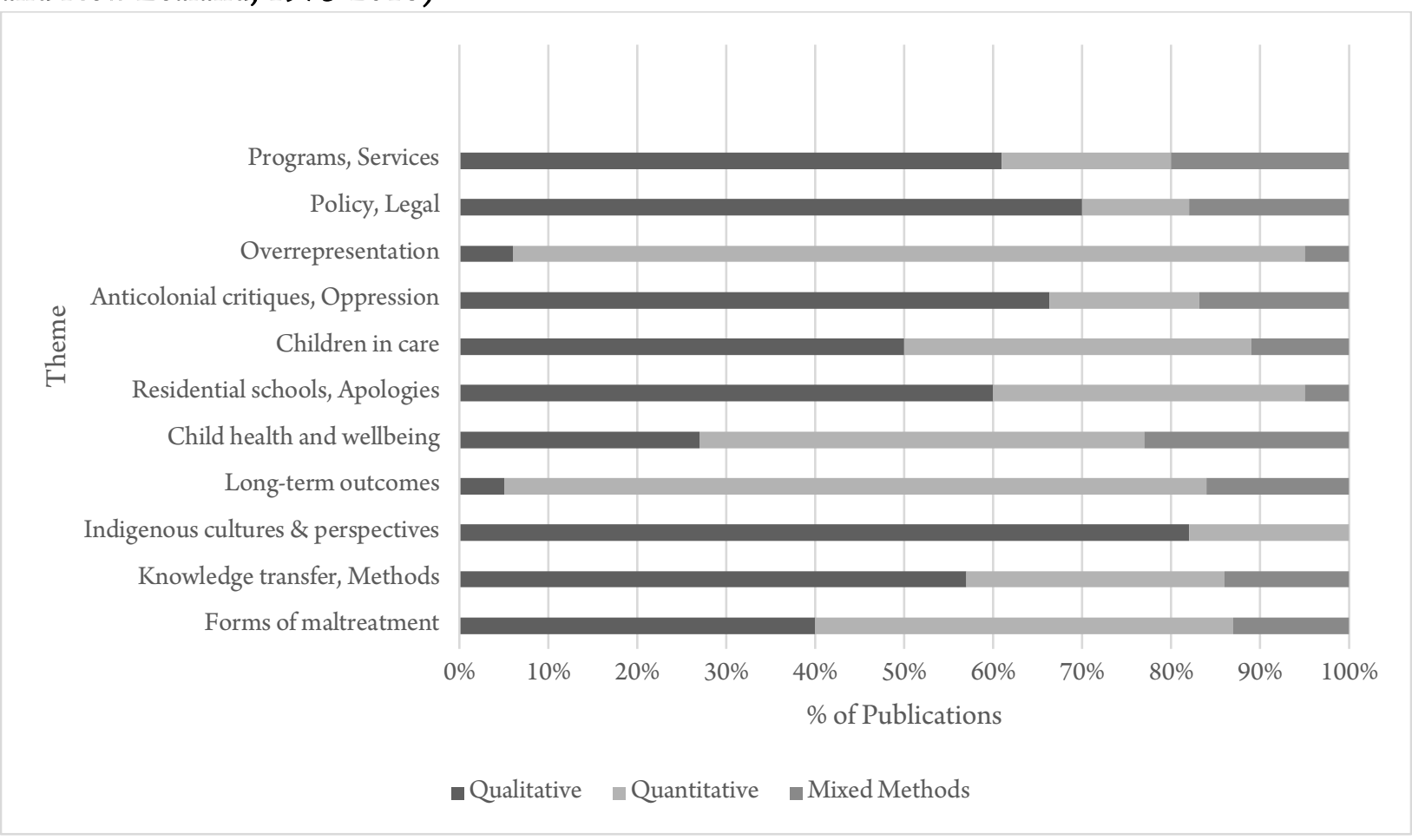

We found that qualitative research was most employed within the majority of the following thematic categories: Indigenous cultures and perspectives (82\%); policy and legal (70\%), anti-colonial critiques and oppression (67\%), programs and services (61\%), and knowledge transfer and methods (57\%). Conversely, the following themes were most present in research using quantitative methods:

\footnotetext{
${ }^{16}$ We considered proportions to be comparable if the difference between the proportion of total literature and proportion of empirical literature was $2 \%$ or less. In addition to child health and wellbeing, this was true for programs and services, residential schools and apologies, Indigenous cultures and perspectives, knowledge transfer and methods, and forms of maltreatment.

${ }^{17}$ The three other themes for which the proportion of empirical literature did not match the percentage of total literature were: children in care, anti-colonial critiques and oppression, and long-term outcomes.
} 
overrepresentation (89\%), long-term outcomes (79\%), and child health and wellbeing (50\%). Mixedmethods research, containing both qualitative and quantitative research methods, was generally the least utilized within each thematic category. It was most used in research coded child health and wellbeing (23\%).

\section{Discussion}

At this critical time of rapid policy and legal development regarding Indigenous involvement in child welfare systems in Canada, the role of research to inform these shifts must be acknowledged. However, the extent to which policy changes support reconciliation efforts depend on how research is consulted, and what voices are included. Cumulatively, a substantial body of research has been produced about Indigenous involvement in child welfare in Canada, the United States, Australia, and New Zealand. Over the decades included in our search, we found 881 publications on this topic. Our search found a marked increase over time in publications based in Canada, the U.S., and Australia, and to a lesser extent in New Zealand. This body of literature covers diverse themes, with increasing attention to the complex settler colonial histories and present-day practices in these countries. We found a particularly large literature base focusing on programs and services as well as policy and legal components of Indigenous child welfare involvement. There was a much smaller amount of literature on knowledge transfer and methods, and specific forms of maltreatment.

Despite the size of the existing literature base identified through our review, recognition and acknowledgement of the limitations of the literature base derived through our review is of critical importance. Some of these limitations are linked to the methods we used in our literature search, others to the substantive focus of the literature reviewed. Our reliance on large academic search tools such as PsycINFO and MEDLINE means that we missed most of the grey literature available on this topic. For example, many organizations working with Indigenous families have produced documents such as program evaluations, legislative summaries, and analyses of funding allocation (e.g., First Nations Child and Family Caring Society, 2020a). Many child- and family-service agencies have invested in further research projects, and some have also thoroughly documented practice models, philosophies, and approaches (e.g., Aboriginal Children in Care Working Group, 2015; Dubois \& Ramdatt, 2006; Goodluck, 2002; Petiquan et al., 2015; Southern First Nations Network of Care, 2019). Our search strategy may also have precluded us finding existing sources in Indigenous-specific databases, which aggregate academic and non-academic sources. ${ }^{18}$ It is difficult to know much about this broad literature base (e.g., how much there is, its scope, and how comparable they are across jurisdictions) due to a lack of centralization of these reports which are sometimes treated as internal documents or are available only directly through individual agencies.

Further, limiting our search to publications that explicitly identified a focus on child welfare or related terms also excluded vitally relevant literature. For example, extant literature demonstrates that neglect investigations are the primary driver of the overrepresentation of Indigenous children (Pew Charitable Trusts, 2007; Sinha et al., 2011; Sinha \& Kozlowski, 2013; Steering Committee for the Review of Government Service Provision, 2014) and that neglect is strongly linked to a broad range of structural

\footnotetext{
${ }^{18}$ Two examples are the Native Health Database at the University of New Mexico and the Indigenous Studies Portal at the University of Saskatchewan.
} 
and family-level risk factors including poverty and challenges related to substance use and mental health (MacEachron \& Gustavsson, 2005; Mulder et al., 2018). Without including these cross-cutting issues, we potentially miss myriad publications relevant to this topic even when no link to child welfare is made in the publication. Finally, unwritten histories and untold experiences are not captured here, nor could they easily be in future scoping reviews. The lack of space for oral histories or ways of knowing in written publications misses crucial insight and context of Indigenous child welfare involvement (e.g., Ormiston, 2010).

Thus, while our search is the broadest and largest we are aware of on this topic, it does not come close to reflecting the Indigenous knowledge on child welfare involvement. Future review or synthesis that is done in the realm of Indigenous involvement in child welfare ought to push beyond reliance on academic search engines and traditional Western, academic standards for assessing literature, lest the most potentially salient publications and experiences be excluded. This will necessitate inclusion of agency-level reports and program evaluations, which means supporting the development of a stronger base of studies produced by and in partnership with Indigenous communities. Failure to expand the range of knowledge that is considered in such reviews in this way means we will continue to ignore a potentially vast body of research and writing produced by, with, and for Indigenous communities, families, and practitioners. Meaningful review, synthesis, and connection to broader bases of research and knowledge that elevate and prioritize Indigenous voices, along with ongoing monitoring of new research production, will necessitate redefining the standards for what a thorough review entails. It will also require significant resources to seek out publications intentionally and proactively, which are currently decentralized.

A number of recent reviews of Indigenous child welfare and related literature demonstrate growing awareness of the need for synthesis of the many dimensions of this broad topic. For example, Macvean et al. (2017) compiled 16 publications on parenting interventions for Indigenous child psychosocial functioning. Similarly, di Tomasso and de Finney (2015a, 2015b) collated numerous sources on Indigenous custom adoption practices in a two-part discussion paper. In a scoping review of 37 studies, Haight et al. (2018) focused on Indigenous involvement in North American child welfare systems. Fiolet et al. (2019) examined 15 articles on Indigenous help-seeking behaviors related to family violence. In a large review of Indigenous youth in residential care in Australia and other countries, Gatwiri et al. (2019) included eight peer-reviewed articles and 51 grey literature publications. Finally, Ritland et al. (2020) reviewed 18 articles on culturally safe parenting programs to support Indigenous families dealing with substance use. Cumulatively, these efforts represent a big step forward for the state of academic knowledge on Indigenous child welfare. Several of them were published after April 2018, which is when we stopped our literature search, indicating increasing attention to the need for synthesis on this topic.

Still, in our review we found few articles that systematically work across existing literature to propose frameworks, create typologies, or consolidate research findings. For example, despite the large number of articles we coded as programs and services, we did not find any pieces that provided clear, explicit discussion of commonalities in terms of approaches, underlying practice values or paradigms, or challenges cutting across these programs and services. Further, we did not find anything that treated variation in findings as a potential strength, examining key contextual factors and correlates of outcome variables in order to make sense of and reconcile disparate findings. Our review suggests that researchers 
are still sorting out how to integrate literature across these academic silos in order to bridge to policy and practice settings.

Accessibility of publications synthesizing literature on Indigenous involvement with child welfare systems is an important concluding point. Among the recent reviews we found on this topic, most exist behind a paywall, meaning they are accessible only to those who have access to academic journals, typically through affiliation with a university. ${ }^{19}$ Beyond this, even when these reviews are available as open-source publications (e.g., di Tomasso \& de Finney, 2015a, 2015b), access to many sources cited within the text are still be limited to those with academic credentials. These paywalls keep important findings from policymakers and practitioners who are best placed to act on learnings from research. While many authors frame their findings as being relevant for policy and practice, the structure and flow of this "knowledge" hinder this translation from taking place.

The investment of sustained public resources in Canada to synthesize, summarize, and publicly disseminate findings from existing research related to Indigenous child welfare involvement would catalyze the potential policy and program development, which could reduce the overrepresentation of Indigenous children in child welfare systems. The United States has several organizations that are publicly mandated and funded to do just this, including the Child Welfare Information Gateway, which collates and disseminates research, statistics, legal information, and practice resources for practitioners and policymakers as well as academic researchers. ${ }^{20}$

Issues of access to content, as well as prioritization of knowledge dissemination for policy and practice, will likely be best addressed through ensuring Indigenous control of these processes. On a basic level, this is needed to help correct the imbalance in current literature. It is also important to promote the trust and collaboration that might facilitate compilation of grey literature (e.g., from practice agencies' program evaluations). Fundamentally, Indigenous control of synthesizing literature about Indigenous child welfare involvement will ensure that these processes reflect Indigenous needs and perspectives. Canada has recently taken steps to acknowledge the disproportionate representation of Indigenous children in its child welfare systems, and passed federal legislation (Bill C-92, 2019) to more adequately acknowledge the importance of Indigenous children's community, cultural, and linguistic ties in the child welfare system, as well as the importance of Indigenous communities' self-determination in decisions affecting local children and families. However, this legislation came without any funds appropriated to support its implementation, and critics suggest that it was not developed with sufficient consultation with local communities, limiting its potential to substantively shift child welfare practices on the ground. At a time when there is an opening for Indigenous child welfare to be redefined at local levels, it is important that Canada make public investments in seeking, consolidating, and learning from the diversity of knowledge related to Indigenous child welfare. Investing in these tasks would contribute not only to enhancing the rigor and quality of research publications in the domain of Indigenous child welfare, but also to increasing the quantity of these publications, in order to inform smarter

\footnotetext{
${ }^{19}$ Without using our own academic credentials, the authors were not able to access several recent review articles (Fiolet et al., 2019; Gatwiri et al., 2019; Haight et al., 2018; Macvean et al., 2017).

${ }^{20}$ In addition, the National Clearinghouse on Families \& Youth, the National Criminal Justice Reference Service, the National Human Trafficking Hotline, and the National Responsible Fatherhood Clearinghouse are all federally funded, centralized hubs for information related to children and families (Child Welfare Information Gateway, 2020).
} 
policymaking that better reflects various lived realities of Indigenous communities in Canada.

\section{References}

Aboriginal Children in Care Working Group. (2015). Aboriginal children in care: Report to Canada's Premiers. https://fncaringsociety.com/sites/default/files/Aboriginal\%20Children\%20in\% 20Care\%20Report $\% 20 \% 28$ July\%202015\%29.pdf

Adams, D. W. (1995). Education for extinction: American Indians and the boarding school experience, 1875-1928. University Press of Kansas.

Adoptive Couple v. Baby Girl, 570 U.S. 637 (2013). https://supreme.justia.com/cases/federal/us/570/ $\underline{637 /}$

Akhtar, Z. (2012). Native family law, Indian Child Welfare Act and tribal sovereignty. First Peoples Child \& Family Review, 7(2). https://doi.org/10.7202/1068846ar

Anderson, M. (2014). Protecting the rights of Indigenous and multicultural children and preserving their cultures in fostering and adoption. Family Court Review, 52(1), 6-27. https://doi.org/ $\underline{10.1111 / \text { fcre. } 12067}$

Arksey, H., \& O’Malley, L. (2005). Scoping studies: Towards a methodological framework. International Journal of Social Research Methodology, 8(1), 19-32. https://doi.org/10.1080/ $\underline{1364557032000119616}$

Armitage, A. (1995). Comparing the policy of Aboriginal assimilation: Australia, Canada, and New Zealand. UBC Press.

Attean, E. A., Burns, P., Proulx, M., Bissonette-Lewey, J., Williams, J., \& Deserly, K. (2012). Truth, healing, and systems change: The Maine Wabanaki-State Child Welfare Truth and Reconciliation Commission process. Child Welfare, 91(3), 15-30.

Australian Institute of Aboriginal and Torres Strait Islander Studies. (2018). Stolen Generations. https://aiatsis.gov.au/research/finding-your-family/before-you-start/stolen-generations

Australian Institute of Family Studies. (2020). Child protection and Aboriginal and Torres Strait Islander children. https://aifs.gov.au/cfca/publications/child-protection-and-aboriginal-andtorres-strait-islander-children

Australian Law Reform Commission. (1997). Seen and heard: Priority for children in the legal process (Report No. ALRC 84). Australian Government Publishing Service. https://www.alrc.gov.au/ publication/seen-and-heard-priority-for-children-in-the-legal-process-alrc-report-84/

Bailey, C., Mace, G., Powell, M., \& Benson, M. (2015). Evaluation of a collaborative operation to improve child sexual abuse reporting in Western Australian Indigenous communities. Criminal 
Justice and Behavior, 42(12), 1303. https://doi.org/10.1177/0093854815603388

Barker, B., Kerr, T., Alfred, G. T., Fortin, M., Nguyen, P., Wood, E., \& DeBeck, K. (2014). High prevalence of exposure to the child welfare system among street-involved youth in a Canadian setting: Implications for policy and practice. BMC Public Health, 14(1), 197. https://doi.org/ $\underline{10.1186 / 1471-2458-14-197}$

Barker-Collo, S. L. (1999). Reported symptomatology of Native Canadian and Caucasian females sexually abused in childhood: A comparison. Journal of Interpersonal Violence, 14(7), 747-760. https://doi.org/10.1177/088626099014007005

Becker-Green, J. (2009). Developing one's self: Adoption and identity formation through the eyes of transracially adopted Native American adults. [Doctoral dissertation, Portland State University]. PDXScholar. https://pdxscholar.library.pdx.edu/open access etds/2792/

Beiser, M. (1974). A hazard to mental health: Indian boarding schools. American Journal of Psychiatry, 131(3), 305-306. https://doi.org/10.1176/ajp.131.3.305

Bending, R. L. (1997). Training child welfare workers to meet the requirements of the Indian Child Welfare Act. Journal of Multicultural Social Work, 5(3/4), 151-164. https://doi.org/ $\underline{10.1300 / \mathrm{J} 285 \mathrm{v} 05 \mathrm{n} 03 \quad 03}$

Bennett, M. (2007). Ensuring knowledge transmission in the Aboriginal child welfare field. First Peoples Child \& Family Review, 3(1), 5-9. https://fpcfr.com/index.php/FPCFR/article/view/20

Bennett, M., Blackstock, C., \& De La Ronde, R. (2005). A literature review and annotated bibliography on aspects of Aboriginal child welfare in Canada. First Nations Child \& Family Caring Society of Canada. https://fncaringsociety.com/sites/default/files/17LitReviewEntire.pdf

Berlin, I. N. (1978). Anglo adoptions of Native Americans: Repercussions in adolescence. Journal of the American Academy of Child Psychiatry, 17(2), 387-388. https://doi.org/10.1016/S0002$\underline{7138(10) 60102-1}$

Berlin, I. N. (1987). Suicide among American Indian adolescents: An overview. Suicide and LifeThreatening Behavior, 17(3), 218-232. https://doi.org/10.1111/j.1943-278X.1987.tb00269.x

Bessarab, D., \& Crawford, F. (2010). Aboriginal practitioners speak out: Contextualising child protection interventions. Australian Social Work, 63(2), 179-193. https://doi.org/ $\underline{10.1080 / 03124071003717663}$

Bill C-92, An Act Respecting First Nations, Inuit and Métis Youth, Children and Families, $1^{\text {st }}$ Sess, $42^{\text {nd }}$ Parl, 2019. https://www.parl.ca/DocumentViewer/en/42-1/bill/C-92/first-reading\#enH203

Bintarsari, N. K. (2018). The cultural genocide in Australia: A case study of the forced removal of Aborigine children from 1912-1962. SHS Web of Conferences, 54(05002), 1-5. https://doi.org/10.1051/shsconf/20185405002 
Blackstock, C. (2009). The final word: After the residential school apology: Why all Canadians should care about a racial equality case before the Canadian Human Rights Commission. First Peoples Child \& Family Review, 4(1), 89-89. https://fpcfr.com/index.php/FPCFR/article/view/80

Blackstock, C. (2011a). The Canadian Human Rights Tribunal on First Nations child welfare: Why if Canada wins, equality and justice lose. Children and Youth Services Review, 33(1), 187-194. https://doi.org/10.1016/j.childyouth.2010.09.002

Blackstock, C. (2011b). Wanted: Moral courage in Canadian child welfare. First Peoples Child \& Family Review, 6(2). https://fpcfr.com/index.php/FPCFR/article/view/114

Blackstock, C. (2016). The complainant: The Canadian human rights case on First Nations child welfare. McGill Law Journal, 62(2), 285-328. https://doi.org/10.7202/1040049ar

Blackstock, C., Trocmé, N., \& Bennett, M. (2004). Child maltreatment investigations among Aboriginal and non-Aboriginal families in Canada. Violence Against Women, 10(8), 901-916. https://doi.org/10.1177/1077801204266312

Bombay, A., Matheson, K., \& Anisman, H. (2013). The intergenerational effects of Indian residential schools: Implications for the concept of historical trauma. Transcultural Psychiatry, 51(3), 320338. https://doi.org/10.1177/1363461513503380

Brittain, M., \& Blackstock, C. (2015). First Nations child poverty: A literature review and analysis. First Nations Children's Action Research and Education Service (FNCARES). https://fncaringsociety.com/publications/first-nations-child-poverty-literature-review-and$\underline{\text { analysis- } 2015}$

Brown, J. D., Sintzel, J., George, N., \& St. Arnault, D. (2010). Benefits of transcultural fostering. Child \& Family Social Work, 15(3), 276-285. https://doi.org/10.1111/j.1365-2206.2009.00668.x

Brown, M. (2017). Bringing them home: Aboriginal children in out of home care still increasing. Australian Broadcasting Corporation. https://www.abc.net.au/news/2017-05-29/bringingthem-home-removal-of-aboriginal-children-on-rise/8564946

Buchanan, L., \& Malcolm, J. (2010). The challenge of providing child health care in the Indigenous population of New Zealand. Journal of Paediatrics and Child Health, 46(9), 471-474. https://doi.org/10.1111/j.1440-1754.2010.01838.x

Burich, K. R. (2007). "No place to go": The Thomas Indian School and the "forgotten" Indian children of New York. Wicazo Sa Review, 22(2), 93-110. https://doi.org/10.1353/wic.2007.0015

Burnette, C. E., \& Figley, C. R. (2016). Historical oppression, resilience, and transcendence: Can a holistic framework help explain violence experienced by Indigenous people? Social Work, 62(1), 1-8. https://doi.org/10.1093/sw/sww065 
Buti, A. (2002). The removal of Aboriginal children: Canada and Australia compared. University of Western Sydney Law Review, 6(1). http://www5.austlii.edu.au/au/journals/UWSLRev/ $\underline{2002 / 2 . h t m l}$

Caldwell, H., \& Sinha, V. (2020). (Re)conceptualizing neglect: Considering the overrepresentation of Indigenous children in child welfare systems in Canada. Child Indicators Research, 13, 481-512. https://doi.org/10.1007/s12187-019-09676-w

Canadian Child Welfare Research Portal. (n.d.). Canadian Incidence Study. https://cwrp.ca/canadianincidence-study

Canadian UNICEF Committee. (2009). Canadian supplement to the State of the World's Children 2009, Aboriginal children's health: Leaving no child behind. UNICEF Canada.

Carriere, J. (2005). Connectedness and health for First Nation adoptees. Paediatrics \& Child Health, 10(9), 545-548. https://doi.org/10.1093/pch/10.9.545

Chadwick, B. A., Albrecht, S. L., \& Bahr, H. M. (1986). Evaluation of an Indian student placement program. Social Casework, 679), 515-524. https://doi.org/10.1177/104438948606700901

Child Welfare Information Gateway. (2020). Federal clearinghouses with information on children and families. https://www.childwelfare.gov/organizations/?CWIGFunctionsaction=rols:main. dspList\&rolType $=$ Custom\&RS ID $=6 \&$ rList $=$ ROL

Children, Young Persons, and Their Families Act 1989, No. 24. https://www.legislation.govt.nz/ act/public/1989/0024/65.0/DLM147088.html

Children's Commissioner. (2016). Population, ages and ethnicities of children. https://www.occ.org.nz/assets/Uploads/StatsOnKids/demographics2016.pdf

Collings, S., Dew, A., Gordon, T., Spencer, M., \& Dowse, L. (2018). Intersectional disadvantage: Exploring differences between Aboriginal and non-Aboriginal parents with intellectual disability in the New South Wales child protection system. Journal of Public Child Welfare, 12(2), 170189. https://doi.org/10.1080/15548732.2017.1379456

Collmeyer, P. M. (1995). From 'Operation Brown Baby' to 'opportunity': The placement of children of color at the boys and girls aid society of Oregon. Child Welfare, 74(1), 242-263.

Conifer, D. (2017, May 26). Bringing them home: 20 years after report, Indigenous children worse off than before. ABC News. https://www.abc.net.au/news/2017-05-26/bringing-them-homereport-20-years-on-children-worse-off/8560568

Connolly, M., \& MacKenzie, M. (1998). Effective participatory practice: Family group conferencing in child protection. Transaction Publishers.

Constitution Act, 1982, Schedule B to the Canada Act 1982 (UK), 1982, c 11. https://www.canlii.org/en/ca/laws/stat/schedule-b-to-the-canada-act-1982-uk-1982-c- 
Cradock, G. (2007). The politics of kith and kin: Observations on the British Columbia government's reaction to the death of Sherry Charlie. First Peoples Child \& Family Review, 3(1), 15-33. https://doi.org/10.7202/1069524ar

Cram, F., Gulliver, P., Ota, R., \& Wilson, M. (2015). Understanding overrepresentation of Indigenous children in child welfare data: An application of the Drake risk and bias models. Child Maltreatment, 20(3), 170-182. https://doi.org/10.1177/1077559515580392

Cripps, K., \& McGlade, H. (2008). Indigenous family violence and sexual abuse: Considering pathways forward. Journal of Family Studies, 14(2-3), 240-253. https://doi.org/10.5172/jfs.327.14.2$\underline{3.240}$

Crofoot, T. L., \& Harris, M. S. (2012). An Indian child welfare perspective on disproportionality in child welfare. Children and Youth Services Review, 34(9), 1667-1674. https://doi.org/ 10.1016/j.childyouth.2012.04.028

Cromer, L. D., Gray, M. E., Vasquez, L., \& Freyd, J. J. (2017). The relationship of acculturation to historical loss awareness, institutional betrayal, and the intergenerational transmission of trauma in the American Indian experience. Journal of Cross-Cultural Psychology, 49 (1), 99-114. https://doi.org/10.1177/0022022117738749

Cross, T., \& Blackstock, C. (2012). Special foreword: We are the manifestations of our ancestors' prayers. Child Welfare, 91(3), 9. https://pubmed.ncbi.nlm.nih.gov/23444786/

Cross, T. L. (2014). Customary adoption for American Indian and Alaskan Native children. In G. Mallon \& P. M. Hess (Eds.), Child Welfare for the twenty-first century: A handbook of practices, policies, \& programs (pp. 373-381). Columbia University Press.

Cunneen, C. (2015). Surveillance, stigma, removal: Indigenous child welfare and juvenile justice in the age of neoliberalism. Australian Indigenous Law Review, 19(1), 32-45. https://ssrn.com/ $\underline{\text { abstract }=2888186}$

Cunneen, C., \& Libesman, T. (2000). Postcolonial trauma: The contemporary removal of Indigenous children and young people from their families in Australia. Australian Journal of Social Issues, 35(2), 99-115. https://doi.org/10.1002/j.1839-4655.2000.tb01088.x

Dalley, B. (1998). Moving out of the realm of myth: Government child welfare services to Maori, 19251972. New Zealand Journal of History, 32(2), 189-207. http://www.nzjh.auckland.ac.nz/ docs/1998/NZJH_32_2 06.pdf

D’Souza, N. (1994). Indigenous child welfare or institutionalized colonialism? Social Alternatives, 13(1), 32-34.

Dabbagh, O. (2017). Two decades after the Bringing Them Home report was released, victims and families believe Australia has not made enough profess to help the Stolen Generations and 
affected communities. https://www.sbs.com.au/news/communities-slam-slow-progress-20years-since-stolen-generations-report

Davis, T. (2017). Warning signals: Indigenous remembrance and futurity in post-apology Australia: A reflection from Broome. Australian Humanities Review, 61, 58-73. http://australianhumanitiesreview.org/wp-content/uploads/2017/06/AHR61_Davis.pdf

de Finney, S., Green, J., \& Brown, L. (2009). Towards transformational research for and with Indigenous communities: The new British Columbia Indigenous Child Welfare Research Network. First Peoples Child \& Family Review, 4(2), 161-164. https://fpcfr.com/index.php/ FPCFR/article/view/170/127

de la Sablonnière-Griffin, M., Sinha, V., Esposito, T., Chabot, M., \& Trocmé, N. (2016). Analyzing the trajectories of First Nations youths subject to the Youth Protection Act: Analysis of mainstream youth protection agencies administrative data. First Nations of Quebec and Labrador Health and Social Services Commission. https://www.cssspnql.com/docs/default-source/defaultdocument-library/analysis-project-on-the-trajectories---component-3---eng.pdf?sfvrsn $=0$

de Leeuw, S., Greenwood, M., \& Cameron, E. (2010). Deviant constructions: How governments preserve colonial narratives of addictions and poor mental health to intervene into the lives of Indigenous children and families in Canada. International Journal of Mental Health and Addiction, 8(2), 282-295. https://doi.org/10.1007/s11469-009-9225-1

Deitrich, G. (1982). Indian Child Welfare Act: Ideas for implementation. Child Abuse \& Neglect, 6(2), 125-128. https://doi.org/10.1016/0145-2134(82)90004-7

Delfabbro, P., Hirte, C., Rogers, N., \& Wilson, R. (2010). The over-representation of young Aboriginal or Torres Strait Islander people in the South Australian child system: A longitudinal analysis. Children and Youth Services Review, 32(10), 1418-1425. https://doi.org/10.1016/ j.childyouth.2010.06.011

di Tomasso, L., \& de Finney, S. (2015a). A discussion paper on Indigenous custom adoption Part 1: severed connections-historical overview of Indigenous adoption in Canada. First Peoples Child \& Family Review, 1O(1), 1-18. https://fpcfr.com/index.php/FPCFR/article/view/247

di Tomasso, L., \& de Finney, S. (2015b). A discussion paper on Indigenous custom adoption Part 2: Honouring our caretaking traditions. First Peoples Child \& Family Review, 10(1), 19-38. https://fpcfr.com/index.php/FPCFR/article/view/248

Dubois, D., \& Ramdatt, J. (2006). Promising practices in First Nations child welfare management and governance. Touchwood Child and Family Services: Reflecting on the elements of good leadership. First Nations Child and Family Caring Society of Canada. https://icwrn.uvic.ca/wpcontent/uploads/2013/10/Touchwood_Agency.pdf

Dumont, R. T. (1988). Culturally selective perceptions in child welfare decisions. The Social Worker, $56(4)$. 
Evans-Campbell, T. (2008). Perceptions of child neglect among urban American Indian/Alaska Native parents. Child Welfare, $87(3), 115-142$. https://pubmed.ncbi.nlm.nih.gov/19189807/

Fejo-King, C. (2011). The national apology to the Stolen Generations: The ripple effect. Australian Social Work, 64(1), 130-143. https://doi.org/10.1080/0312407X.2010.542564

Fernandez, E., Lee, J.-S., Foote, W., Blunden, H., McNamara, P., Kovacs, S., \& Cornefert, P.-A. (2017). 'There's more to be done; "sorry" is just a word': Legacies of out-of-home care in the 20th century. Children Australia, 42(3), 176-197. https://doi.org/10.1017/cha.2017.29

Filipetti, C. (2016). The treatment of Aboriginal children in Canada: A violation of human rights demanding remedy. First Peoples Child \& Family Review, 11(2), 60-68. https://fpcfr.com/ index.php/FPCFR/article/view/307

Fiolet, R., Tarzia, L., Hameed, M., \& Hegarty, K. (2019). Indigenous Peoples' help-seeking behaviors for family violence: A scoping review. Trauma, Violence, \& Abuse, 22(2), 1-11. https://doi.org/ $\underline{10.1177 / 1524838019852638}$

First Nations Child and Family Caring Society. (2020a). Indigenous Knowledge Portal. https://fncaringsociety.com/ikp

First Nations Child and Family Caring Society. (2020b). I am a witness: Tribunal timeline and documents. https://fncaringsociety.com/i-am-witness-tribunal-timeline-and-documents

First Nations Child and Family Caring Society and Assembly of First Nations v. Attorney General of Canada (January 26, 2016), 2016 CHRT 2. https://fncaringsociety.com/sites/default/ files/2016 chrt 2 access $0 . p d f$

First Nations Child and Family Caring Society and Assembly of First Nations v. Attorney General of Canada (April 26, 2016), 2016 CHRT 10. https://fncaringsociety.com/sites/default/ files $/ 2016$ chrt $10 . \mathrm{pdf}$

First Nations Child and Family Caring Society and Assembly of First Nations v. Attorney General of Canada (September 14, 2016), 2016 CHRT 16. https://fncaringsociety.com/sites/default/ files $/ 2016 \% 20$ CHRT\%2016\%20-\%20September\%2015.pdf

First Nations Child and Family Caring Society and Assembly of First Nations v. Attorney General of Canada (March 29, 2017), 2017 CHRT 17. https://fncaringsociety.com/sites/default/ files/2017 chrt 7 corrected.pdf

First Nations Child and Family Caring Society and Assembly of First Nations v. Attorney General of Canada (May 26, 2017), 2017 CHRT 14. https://fncaringsociety.com/sites/default/ files $/ 2017$ chrt 14.pdf

First Nations Child and Family Caring Society and Assembly of First Nations v. Attorney General of Canada (February 1, 2018), 2018 CHRT 4. https://fncaringsociety.com/sites/default/ files $/ 2018$ chrt_4_1.pdf 
First Nations Child and Family Caring Society and Assembly of First Nations v. Attorney General of Canada (February 21, 2019), 2019 CHRT 7. https://fncaringsociety.com/sites/default/ files $/ 2019$ chrt $7 . \mathrm{pdf}$

First Nations Child and Family Caring Society and Assembly of First Nations v. Attorney General of Canada (September 6, 2019), 2019 CHRT 39. https://fncaringsociety.com/sites/default/ files/2019 chrt 39.pdf

Forbes, M. (Host), \& Stevanon, A. (Director). (2017). Ngā Mōrehu-Survivors of State abuse. [Television series episode]. In J. Hoani (Producer), The Hui. NZ On Screen. https://www.nzonscreen.com/title/the-hui-nga-morehu-state-abuse-2017/overview

Fraser, J. (2013). Responsible use of child welfare and administrative datasets to build the capacity of child abuse and neglect prevention research internationally. Child Abuse \& Neglect, 37(2-3), 87. https://doi.org/10.1016/j.chiabu.2012.12.010

Freeman, B. J., Coll, K. M., Two Dogs, R., Iron Cloud Two Dogs, E., Iron Cloud, E., \& Robertson, P. (2016). The value of Lakota traditional healing for youth resiliency and family functioning. Journal of Aggression, Maltreatment \& Trauma, 25(5), 455-469. https://doi.org/10.1080/ $\underline{10926771.2015 .1079282}$

Gatwiri, K., McPherson, L., Parmenter, N., Cameron, N., \& Rotumah, D. (2019, October 30). Indigenous children and young people in residential care: A systematic scoping review. Trauma, Violence, \& Abuse, 1-14. https://doi.org/10.1177/1524838019881707

Glover, G. (2001). Parenting in Native American families. In N. B. Webb (Ed.), Culturally diverse parent-child and family relationships: A guide for social workers and other practitioners. (pp. 205-231). Columbia University Press.

Goodluck, C. (2002). Native American children and youth well-being indicators: A strengths perspective. National Indian Child Welfare Association. yumpu.com/en/document/read/ 41169999/native-american-children-and-youth-well-being-indicators

Green, H. J. (1983). Risks and attitudes associated with extra-cultural placement of American Indian children: A critical review. Journal of the American Academy of Child Psychiatry, 22(1), 63-67. https://doi.org/10.1097/00004583-198301000-00010

Green, J., Taylor, R., Larken, R., Brier, M., \& Good, T. (2010). Voices of students: We are here! We are ready to care for the next generations! "Gathering \& Sharing Wisdom Conference" and the Indigenous Child Welfare Research Network. First Peoples Child \& Family Review, 5(1), 1521. https://fncaringsociety.com/sites/default/files/online-journal/vol5num1/Green-TaylorLarken-Brier-Good pp15.pdf

Guest, G., MacQueen, K., \& Namey, E. E. (2011). Applied thematic analysis. SAGE Publications Inc.

Hackell, M. (2016). Managing anxiety: Neoliberal modes of citizen subjectivity, fantasy and child abuse 
in New Zealand. Citizenship Studies, 20(6-7), 867-882. https://doi.org/10.1080/ $\underline{13621025.2016 .1204270}$

Haebich, A. (2016). Neoliberalism, settler colonialism and the history of Indigenous child removal in Australia. Australian Indigenous Law Review, 19(1), 20-31. https://pdfs.semanticscholar.org/ $\underline{847 \mathrm{~d} / 3 \mathrm{c} 9514 \mathrm{fa} 8 \mathrm{~d} 702536740 \mathrm{~b} 62 \mathrm{c} 0423207959 \mathrm{f} 66 . \mathrm{pdf}}$

Haight, W., Waubanascum, C., Glesener, D., \& Marsalis, S. (2018). A scoping study of Indigenous child welfare: The long emergency and preparations for the next seven generations. Children and Youth Services Review, 93, 397-410. https://doi.org/10.1016/j.childyouth.2018.08.016

Halverson, K., Puig, M. E., \& Byers, S. R. (2002). Culture loss: American Indian family disruption, urbanization and the Indian Child Welfare Act. Child Welfare, 81(2), 319-336. https://pubmed.ncbi.nlm.nih.gov/12014471/

Hamilton, G., Brubacher, S. P., \& Powell, M. B. (2016). Investigative interviewing of Aboriginal children in cases of suspected sexual abuse. Journal of Child Sexual Abuse, 25(4), 363-381. https://doi.org/10.1080/10538712.2016.1158762

Hanna, M. D., Boyce, E. R., \& Yang, J. (2017). The impact of historical trauma and mistrust on the recruitment of resource families of color. Adoption Quarterly, 20(1), 65-82. https://doi.org/ $\underline{10.1080 / 10926755.2016 .1149536}$

Harding, R. (2009). News reporting on Aboriginal child welfare: Discourses of White guilt, reverse racism, and failed policy. Canadian Social Work Review/Revue Canadienne de service social, 26(1), 25-41.

Harms, L., Middleton, J., Whyte, J., Anderson, I., Clarke, A., Sloan, J., Hagel, M., \& Smith, M. (2011). Social work with Aboriginal clients: Perspectives on educational preparation and practice. Australian Social Work, 64(2), 156-168. https://doi.org/10.1080/0312407X.2011.577184

Hélie, S., Laurier, C., Pineau-Villeneuve, C., \& Royer, M.-N. (2013). A developmental approach to the risk of a first recurrence in child protective services. Child Abuse \& Neglect, 37(12), 1132-1141. https://doi.org/10.1016/j.chiabu.2013.05.001

Hill, L. (2016). Haudenosaunee grandmothers caring for their grandchildren: The process of assuming the caregiving role. Journal of Gerontological Social Work, 59(4), 281-295. https://doi.org/ $\underline{10.1080 / 01634372.2016 .1214660}$

Hill, R. B. (2008). Gaps in research and public policies. Child Welfare, 87(2), 359. https://pubmed. ncbi.nlm.nih.gov/18972947/

Hodgson, M. (1990). Shattering the silence: Working with violence in Native communities. In T. A. Laidlaw \& C. Malmo (Eds.), Healing voices: Feminist approaches to therapy with women (pp. 33-44). Jossey-Bass.

Howard-Wagner, D. (2015). Child wellbeing and protection as a regulatory system in the neoliberal age: 
Forms of Aboriginal agency and resistance engaged to confront the challenges for Aboriginal people and community-based Aboriginal organisations. Australian Indigenous Law Review, 19(1), 88-102. https://www.jstor.org/stable/10.2307/26423305

Hudson, P., \& McKenzie, B. (2003). Extending Aboriginal control over child welfare services: The Manitoba child welfare initiative. Canadian Review of Social Policy/Revue canadienne de politique sociale, 51, 49-66. http://www.yorku.ca/crsp/issue51/issue51-4.pdf

Hughes, J., Chau, S., \& Rocke, C. (2016). “Act like my friend”: Mothers' recommendations to improve relationships with their Canadian child welfare workers. Canadian Social Work Review/Revue Canadienne de service social, 33(2), 161-177. https://doi.org/10.7202/1038697ar

Human Rights and Equal Opportunity Commission (HREOC). (1997). Bringing them home: Report of the National Inquiry into the Separation of Aboriginal and Torres Strait Islander Children from their Families. https://humanrights.gov.au/sites/default/files/content/pdf/ social_justice/bringing them home_report.pdf

Hyslop, I. (2017). Child protection in New Zealand: A history of the future. The British Journal of Social Work, 47(6), 1800-1817. https://doi.org/10.1093/bjsw/bcx088

Indian Child Welfare Act of 1978 (25 U.S.C. SS 1901-63).

Jacobs, M. D. (2006). Indian boarding schools in comparative perspective: The removal of Indigenous children in the United States and Australia, 1880-1940. Faculty Publications, Department of History, 20, 202-231. https://digitalcommons.unl.edu/cgi/viewcontent.cgi?article=1019 \&context=historyfacpub

Jacobs, M. D. (2014). The fostering \& adoption of Indigenous children in the postwar world. University of Nebraska Press.

Johnston, P. (1983). Native children and the child welfare system. James Lorimer \& Company.

Jones, A., \& Sinha, V. (2015). Long-term trends in out of home care for on reserve First Nations children (CWRP Information Sheet \#164E). Centre for Research on Children and Families. https://cwrp.ca/sites/default/files/publications/164e.pdf

Jordan's Principle Working Group. (2015). Without denial, delay, or disruption: Ensuring First Nations children's access to equitable services through Jordan's Principle. Assembly of First Nations. https://www.afn.ca/uploads/files/jordans principle-report.pdf

Joshua, P., Zwi, K., Moran, P., \& White, L. (2015). Prioritizing vulnerable children: Why should we address inequity? Child Care, Health and Development, 41(6), 818-826. https://doi.org/ $\underline{10.1111 / \mathrm{cch} .12264}$

Keddell, E. (2017). The vulnerable child in neoliberal contexts: The construction of children in the Aotearoa New Zealand child protection reforms. Childhood, 25(1), 93-108. https://doi.org/ $\underline{10.1177 / 0907568217727591}$ 
Kennedy-Kish, B., Sinclair, R., Carniol, B., \& Baines, D. (2017). Case critical: Social services and social justice in Canada. Between the Lines.

Kenney, M. K., \& Singh, G. K. (2016). Adverse childhood experiences among American Indian/Alaska Native children: The 2011-2012 National Survey of Children's Health. Scientifica, 2016. https://doi.org/10.1155/2016/7424239

King, J. (2012). “But how could anyone rationalize policies that discriminate?”: Understanding Canada's failure to implement Jordan's Principle. First Peoples Child \& Family Review, 7(1). https://doi.org/10.7202/1068863ar

Klamn, R. (2009). Helping First Nations children-in-care develop a healthy identity [Master's thesis, Royal Roads University]. https://viurrspace.ca/bitstream/handle/10170/134/Klamn\%2C\% 20Rosemarri.pdf? sequence $=1$ \&isAllowed $=y$

Kreitzer, L., \& Lafrance, J. (2010). Co-location of a government child welfare unit in a traditional Aboriginal agency: A way forward in working in Aboriginal communities. First Peoples Child \& Family Review, 5(2), 34-44. https://fpcfr.com/index.php/FPCFR/article/view/91

Kuipers, A. (2015). The education of Augie Merasty: A residential school memoir by Joseph Auguste Merasty with David Carpenter [Book review]. Engaged Scholar Journal: Community-Engaged Research, Teaching, and Learning, 1(2), 234-235. https://doi.org/10.15402/esj.v1i2.122

Landertinger, L. (2016). 'Hell holes': Unmapping settler colonial geographies and child welfare in Manitoba. Borderlands, 15(1). https://go.gale.com/ps/anonymous?id=GALE\% 7CA499577268\&sid=googleScholar\&v=2.1\&it=r\&linkaccess=abs\&issn=14470810\&p=AONE $\underline{\& \mathrm{sw}=\mathrm{w}}$

Leung, E., Wekerle, C., Weachter, R., Egelstaff, J., \& Bennett, M. (2011). Non-Aboriginal child protective service workers' utilization of the Maltreatment and Adolescent Pathway Knowledge Translation (MAP-KT) Portal: A report on the utilization statistics and utilization gaps of Aboriginal best-practice material. First Peoples Child \& Family Review, 6(2), 7-13. https://fpcfr.com/index.php/FPCFR/article/view/111

Lett, D. (2008). Whatever happened to Jordan's Principle? Canadian Medical Association Journal, 178(12), 1534-1535. https://doi.org/10.1503/cmaj.080692

Levac, D., Colquhoun, H., \& O’Brien, K. K. (2010). Scoping studies: Advancing the methodology. Implementation Science, 5(1), 69. https://doi.org/10.1186/1748-5908-5-69

Libesman, T. (2014). Decolonising Indigenous child welfare: Comparative perspectives. Routledge.

Libesman, T. (2015). Indigenous child welfare post bringing them home: From aspirations for selfdetermination to neoliberal assimilation. Australian Indigenous Law Review, 19(1), 46-61. https://www.jstor.org/stable/10.2307/26423302

Limb, G. E., Hodge, D. R., \& Panos, P. (2008). Social work with Native people: Orienting child welfare 
workers to the beliefs, values, and practices of Native American families and children. Journal of Public Child Welfare, 2(3), 383-397. https://doi.org/10.1080/15548730802463595

Lindstrom, G., \& Choate, P. W. (2016). Nistawatsiman: Rethinking assessment of Aboriginal parents for child welfare following the Truth and Reconciliation Commission. First Peoples Child \& Family Review, 11(2), 45-59. https://fpcfr.com/index.php/FPCFR/article/view/305

Liu, D. M., \& Alameda, C. K. (2011). Social determinants of health for Native Hawaiian children and adolescents. Hawaii Medical Journal, 7O(11, Suppl 2), 9-14.

Lonne, B., \& Gillespie, K. (2014). How do Australian print media representations of child abuse and neglect inform the public and system reform? Child Abuse \& Neglect, 38(5), 837-850. https://doi.org/10.1016/j.chiabu.2014.04.021

Lujan, C., DeBruyn, L. M., May, P. A., \& Bird, M. E. (1989). Profile of abused and neglected American Indian children in the Southwest. Child Abuse \& Neglect, 13(4), 449-461. https://doi.org/ $\underline{10.1016 / 0145-2134(89) 90049-5}$

MacDonald, N., \& Attaran, A. (2007). Jordan's Principle, governments' paralysis. Canadian Medical Association Journal, 177(4), 321-323. https://doi.org/10.1503/cmaj.070950

MacDonald, R., \& Ladd, P. (2000). Joint national policy review on First Nations child and family services. Assembly of First Nations. https://www.afn.ca/uploads/Social_Development/ National\%20Policy\%20Review\%202000 en\%20only.pdf

MacDonald, F., \& Levasseur, K. (2014). Accountability insights from devolution of Indigenous child welfare in Manitoba. Canadian Public Administration, 57(1), 97-117. https://doi.org/ $\underline{10.1111 / \text { capa. } 12052}$

MacEachron, A. E., \& Gustavsson, N. (2005). Contemporary policy challenges for Indian child welfare. Journal of Poverty, 9(2), 43-61. https://doi.org/10.1300/J134v09n02_03

Macvean, M., Shlonsky, A., Mildon, R., \& Devine, B. (2017). Parenting interventions for Indigenous child psychosocial functioning: A scoping review. Research on Social Work Practice, 27(3), $307-$ 334. https://doi.org/10.1177\%2F1049731514565668

Malvaso, C. G., Delfabbro, P. H., \& Day, A. (2017). The child protection and juvenile justice nexus in Australia: A longitudinal examination of the relationship between maltreatment and offending. Child Abuse \& Neglect, 64, 32-46. https://doi.org/10.1016/j.chiabu.2016.11.028

Matheson, K., Bombay, A., Haslam, S. A., \& Anisman, H. (2016). Indigenous identity transformations: The pivotal role of student-to-student abuse in Indian residential schools. Transcultural Psychiatry, 53(5), 551-573. https://doi.org/10.1177\%2F1363461516664471

Maxwell, K. (2014). Historicizing historical trauma theory: Troubling the trans-generational transmission paradigm. Transcultural Psychiatry, 51(3), 407-435. https://doi.org/10.1177/ $\underline{1363461514531317}$ 
May, H., Kaur, B., \& Prochner, L. (2014). Empire, education, and Indigenous childhoods: Nineteenthcentury missionary infant schools in three British colonies. Ashgate.

Maydell, E. (2018). 'It just seemed like your normal domestic violence': Ethnic stereotypes in print media coverage of child abuse in New Zealand. Media, Culture \& Society, 40(5), 707-724. https://doi.org/10.1177\%2F0163443717737610

McAuliffe, D., Tilbury, C., Chenoweth, L., Stehlik, D., Struthers, K., \& Aitchison, R. (2016). (Re)valuing relationships in child protection practice. Journal of Social Work Practice, 30(4), 365-377. https://doi.org/10.1080/02650533.2015.1116437

McKenzie, B. (1989). Child welfare: New models of service delivery in Canada's Native communities. Human Services in the Rural Environment, 12(3), 6-11.

McKenzie, B. (1997). Developing First Nations child welfare standards: Using evaluation research within a participatory framework. The Canadian Journal of Program Evaluation, 12(1), 133. https://evaluationcanada.ca/system/files/cjpe-entries/12-1-133.pdf

McShane, D. (1988). An analysis of mental health research with American Indian youth. Journal of Adolescence, 11(2), 87-116. https://doi.org/10.1016/S0140-1971(88)80047-2

Mech, E. V. (1983). Out-of-home placement rates. Social Service Review, 57(4), 659-667. https://doi.org/10.1086/644145

Milloy, J. S. (2017). A national crime: The Canadian government and the residential school system, 1879 to 1986. University of Manitoba Press.

Ministry of Social Development. (2017). Kids in care. https://www.msd.govt.nz/about-msd-and-ourwork/publications-resources/statistics/cyf/kids-in-care.html

Moffat, T. (1994). Infant mortality and cultural concepts of infancy: A case study from an early twentieth century Aboriginal community. Pre- and Peri-natal Psychology Journal, 8(4), 259273.

Montgomery-Andersen, R, \& Borup, I. (2012). Family support and the child as health promoting agent in the Arctic_-"the Inuit way." Rural and Remote Health, 12(2), 1977. https://pubmed.ncbi. nlm.nih.gov/22553986/

Moorehead, V., \& LaFromboise, T. D. (2014). Healing one story at a time: American Indian/Alaska Native social justice. In C. V. Johnson \& H. L. Friedman (Eds.), The Praeger Handbook of Social Justice and Psychology (Vol. 1, pp. 135-154). Praeger.

Moss, M. (2009). Broken circles to a different identity: An exploration of identity for children in out-ofhome care in Queensland, Australia. Child \& Family Social Work, 14(3), 311-321. https://doi.org/10.1111/j.1365-2206.2008.00598.x

Mota, N., Elias, B., Tefft, B., Medved, M., Munro, G., \& Sareen, J. (2012). Correlates of suicidality: 
Investigation of a representative sample of Manitoba First Nations adolescents. American Journal of Public Health, 102(7), 1353-1361. https://doi.org/10.2105/AJPH.2011.300385

Mulder, T. M., Kuiper, K. C., van der Put, C. E., Stams, G. J. M., \& Assink, M. (2018). Risk factors for child neglect: A meta-analytic review. Child Abuse and Neglect, 77, 198-210. https://doi.org/ $\underline{10.1016 / j . c h i a b u .2018 .01 .006}$

Mutchler, J. E., Baker, L. A., \& Lee, S. (2007). Grandparents responsible for grandchildren in NativeAmerican families. Social Science Quarterly, 88(4), 990-1009. https://doi.org/10.1111/j.1540$\underline{6237.2007 .00514 . x}$

Myhra, L. L., Wieling, E., \& Grant, H. (2015). Substance use in American Indian family relationships: Linking past, present, and future. The American Journal of Family Therapy, 43(5), 413-424. http://doi.org/10.1080/01926187.2015.1069133

National Data Archive on Child Abuse and Neglect. (2020). Datasets. https://www.ndacan.acf. hhs.gov/datasets/datasets-list.cfm

National Indian Child Welfare Association. (2017). What is disproportionality in child welfare? https://www.nicwa.org/wp-content/uploads/2017/09/Disproportionality-Table.pdf

Navia, D., Henderson, R. I., \& First Charger, L. (2018). Uncovering colonial legacies: Voices of Indigenous youth on child welfare (dis)placements. Anthropology \& Education Quarterly, 49(2), 146-164. http://doi.org/10.11575/PRISM/28554

Neckoway, R. (2011). The role of culture in parenting: Some Ojibway parents' perspectives [Doctoral dissertation, Memorial University]. https://research.library.mun.ca/12285/

Neckoway, R., Brownlee, K., \& Castellan, B. (2007). Is attachment theory consistent with Aboriginal parenting realities? First People's Family Review, 3(2), 65-74. https://fpcfr.com/index.php/ $\underline{\text { FPCFR/article/view/43 }}$

Neckoway, R., Brownlee, K., Jourdain, L. W., \& Miller, L. (2003). Rethinking the role of attachment theory in child welfare practice with Aboriginal people. Canadian Social Work Review/Revue Canadienne de service social, 20(1), 105-119. http://www.jstor.com/stable/41670000

Nelson, K., Cross, T., Landsman, M. J., \& Tyler, M. (1996). Native American families and child neglect. Children and Youth Services Review, 18(6), 505-521. https://doi.org/10.1016/0190$\underline{7409(96) 00020-5}$

Newton, B. J. (2017). An Aboriginal community's perceptions and experiences of child neglect in a rural town. Australian Journal of Social Issues, 52(3), 262-277. https://doi.org/10.1002/ajs4.18

Ney, T., Bortoletto, C., \& Maloney, M. (2013). Strategies to revive traditional decision-making in the context of child protection in northern British Columbia. First Peoples Child \& Family Review, 7(2), 60-72. https://fpcfr.com/index.php/FPCFR/article/view/218 
Nordberg, A., Delva, J., \& Horner, P. (2014). Adolescent pregnancy in Canada: Multicultural considerations, regional differences, and the legacy of liberalization. In A. Cherry \& M. Dillon (Eds.), International Handbook of Adolescent Pregnancy (pp. 205-223). Springer.

O'Connor, I. (1994). The new removals: Aboriginal youth in the Queensland juvenile justice system. International Social Work, 37(3), 197-212. https://doi.org/10.1177\%2F002087289403700302

O’Donnell, M., Nassar, N., Leonard, H., Mathews, R., Patterson, Y., \& Stanley, F. (2010). Monitoring child abuse and neglect at a population level: Patterns of hospital admissions for maltreatment and assault. Child Abuse and Neglect, 34(11), 823-832. https://doi.org/10.1016/j.chiabu. $\underline{2010.04 .003}$

Oranga Tamariki. (2019). Who we are. Oranga Tamariki Ministry for Children. https://www.orangatamariki.govt.nz/about-us/overview/

Ormiston, N. T. (2010). Re-conceptualizing research: An Indigenous perspective. First Peoples Child \& Family Review, 5(1), 50-56. https://fncaringsociety.com/sites/default/files/onlinejournal/vol5num1/Ormiston_pp50.pdf

Padilla, J., \& Summers, A. (2011). Disproportionality rates for children of color in foster care (Report No. 2009-MU-MU-K001). National Council of Juvenile and Family Court Judges. https://www.ncjrs.gov/App/Publications/abstract.aspx? ID=261612

Palmer, S., \& Cooke, W. (1996). Understanding and countering racism with First Nations children in out-of-home care. Child Welfare, 75(6), 709-725.

Paul, J. (2016). Evaluation of child protection in federalist countries: Recommendations for increasing effectiveness and re-establishing self-determination within Indigenous communities. Journal of Policy Practice, 15(3), 188-211. https://doi.org/10.1080/15588742.2015.1044685

Petiquan, D., Bobinski, T., Trudeau, M., Fortier, M., Ireland, E., Richard, K., Kennedy, K., Spoon, J., Skye, A., Longboat, L., \& McGinnis, L. (2015). A summary report of prevention programs and services across Aboriginal child welfare agencies in Ontario. Association of Native Child and Family Services Agencies of Ontario. https://ancfsao.files.wordpress.com/2019/07/ancfsaoprevention-programs-dec-1-2015.pdf

Pew Charitable Trusts. (2007). Time for reform: A matter of justice for American Indian and Alaskan Native children. Kids are Waiting \& National Indian Child Welfare Association. https://www.pewtrusts.org/-/media/legacy/uploadedfiles/wwwpewtrustsorg/reports/ foster_care reform/nicwareportpdf.pdf

Piasecki, J. M., Manson, S. M., Biernoff, M. P., Hiat, A. B., Taylor, S. S., \& Bechtold, D. W. (1989). Abuse and neglect of American Indian children: Findings from a survey of federal providers. American Indian and Alaska Native Mental Health Research, 3(2), 43-62. https://doi.org/10.5820/ aian.0302.1989.43 
Pihama, L., Te Nana, R., Cameron, N., Smith, C., Reid, J., \& Southey, K. (2016). Māori cultural definitions of sexual violence. Sexual Abuse in Australia and New Zealand, 7(1), 43. https://researchcommons.waikato.ac.nz/bitstream/handle/10289/12338/Ma\%CC\%84ori\%2 0Cultural\%20Definitions\%20of\%20Sexual\%20Violence.pdf? sequence=11\&isAllowed=y

Pike, I., \& First Nations and Inuit Children and Youth Injury Indicators Working Group. (2011). Indicateurs pour la prévention des blessures chez les enfants et les jeunes Inuits [Indicators for injury prevention in Inuit children and youth]. Groupe de travail sur les indicateurs de blessure chez les enfants et les jeunes des Premières Nations et Inuits. https://www.injuryresearch.bc.ca/ wp-content/uploads/2010/11/Inuit-Injury-Indicators-FRENCH.pdf

Poupart, J., Baker, L., \& Horse, J. R. (2009). Research with American Indian communities: The value of authentic partnerships. Children and Youth Services Review, 31(11), 1180-1186.

https://doi.org/10.1016/j.childyouth.2009.08.012

Priest, N., Mackean, T., Davis, E., Briggs, L., \& Waters, E. (2012). Aboriginal perspectives of child health and wellbeing in an urban setting: Developing a conceptual framework. Health Sociology Review, 21(2), 180-195. https://doi.org/10.5172/hesr.2012.21.2.180

Purcal, C., Brennan, D., Cass, B., \& Jenkins, B. (2014). Grandparents raising grandchildren: Impacts of lifecourse stage on the experiences and costs of care. Australian Journal of Social Issues, 49(4), 467-488. https://doi.org/10.1002/j.1839-4655.2014.tb00324.x

Rae, J. (2009). Program delivery devolution: A stepping stone or quagmire for First Nations. Indigenous Law Journal, 7(2), 1-44. https://jps.library.utoronto.ca/index.php/ilj/article/view/ $\underline{27659 / 20390}$

Raman, S., Ruston, S., Irwin, S., Tran, P., Hotton, P., \& Thorne, S. (2017). Taking culture seriously: Can we improve the developmental health and well-being of Australian Aboriginal children in out-ofhome care? Child: Care, Health and Development, 43(6), 899-905. https://doi.org/10.1111/ cch.12488

Read, P. (2006). The Stolen gGenerations: The removal of aboriginal children in New South Wales 1883 to 1969. Department of Aboriginal Affairs. https://daa.asn.au/wp-content/uploads/ 2016/07/Reading-7 StolenGenerations.pdf

Red Horse, J. (1982). Clinical strategies for American Indian families in crisis. Urban and Social Change Review, 2, 17-19.

Reed, J. L. (2010). Family and Nation: Cherokee orphan care, 1835-1903. American Indian Quarterly, 34(3), 312-343. https://doi.org/10.1353/aiq.0.0121

Rensink, B. (2011). Genocide of Native Americans: Historical facts and historiographic debates. Transaction Publishers. https://digitalcommons.unl.edu/cgi/viewcontent.cgi?referer= $\underline{\text { \&httpsredir }=1 \& \text { article }=1034 \& \text { context }=\text { historydiss }}$ 
Reyhner, J., \& Singh, N. K. (2010). Cultural genocide in Australia, Canada, New Zealand, and the United States: The destruction and transformation of Indigenous cultures. Indigenous Policy Journal, 21(4), 1-26. http://www.indigenouspolicy.org/index.php/ipj/article/view/23

Richardson, C., \& Nelson, B. (2007). A change of residence: Government schools and foster homes as sites of forced Aboriginal assimilation-A paper designed to provoke thought and systemic change. First Peoples Child \& Family Review, 3(2), 75-83. https://doi.org/10.7202/1069466ar

Ritland, L., Jongbloed, K., Mazzuca, A., Thomas, V., Richardson, C. G., Spittal, P. M., \& Guhn, M. (2020). Culturally safe, strengths-based parenting programs supporting Indigenous families impacted by substance use-a scoping review. International Journal of Mental Health and Addiction, 18, 1586-1610. https://doi.org/10.1007/s11469-020-00237-9

Ross, A., Dion, J., Cantinotti, M., Collin-Vézina, D., \& Paquette, L. (2015). Impact of residential schooling and of child abuse on substance use problem in Indigenous Peoples. Addictive Behaviors, 51, 184-192. https://doi.org/10.1016/j.addbeh.2015.07.014

Rousseau, J. (2015). The elusive promise of reconciliation in British Columbia child welfare: Aboriginal perspectives and wisdom from within the BC Ministry of Children and Family Development. First Peoples Child \& Family Review, 10(2), 44-61. https://fpcfr.com/index.php/FPCFR/ article/view/276

Schmid, J., \& Pollack, S. (2004). Family group conferencing: A mechanism for empowerment? Canadian Review of Social Policy, 54, 128-134.

Shah, M. F., Liu, Q., Mark Eddy, J., Barkan, S., Marshall, D., Mancuso, D., Lucenko, B., \& Huber, A. (2017). Predicting homelessness among emerging adults aging out of foster care. American Journal of Community Psychology, 60(1-2), 33-43. https://doi.org/10.1002/ajcp.12098

Sherwood, J. (2015). Intergenerational trauma isn't just another determinant of Indigenous Peoples' health. Journal of Ethics in Mental Health, 1, 1-7. https://jemh.ca/issues/v9/ documents/JEMH_Open-Volume_Article_Theme_Colonization_Intergenerational Trauma June2015.pdf

Simon, J. A., \& Smith, L. T. (2001). A civilising mission? Perceptions and representations of the New Zealand Native schools system. Auckland University Press.

Sinclair, R. (2008). All my relations Native transracial adoption: A critical case study of cultural identity (Publication No. 304898656) [Doctoral Dissertation, University of Calgary]. ProQuest Dissertations Publishing.

Sinha, V., \& Kozlowski, A. (2013). The structure of Aboriginal child welfare in Canada. The International Indigenous Policy Journal, 4(2). https://doi.org/10.18584/iipj.2013.4.2.2

Sinha, V., Trocmé, N., Fallon, B., \& MacLaurin, B. (2013). Understanding the investigation-stage overrepresentation of First Nations children in the child welfare system: An analysis of the First 
Nations component of the Canadian Incidence Study of Reported Child Abuse and Neglect 2008. Child Abuse \& Neglect, 37(10), 821-831. https://doi.org/10.1016/j.chiabu.2012.11.010

Sinha, V., Trocmé, N., Fallon, B., MacLaurin, B., Fast, E., Prokop, S. T., \& Richard, K. (2011). Kiskisik awasisak: Remember the children. Understanding the overrepresentation of First Nations children in the child welfare system. Assembly of First Nations. https://cwrp.ca/sites/default/ files/publications/en/FNCIS-2008_March2012_RevisedFinal.pdf

Slee, R. (2010). 'Inclusion in practice': Does practice make perfect? Educational Review, 53(2), 113123. https://doi.org/10.1080/00131910120055543

Smallwood, G. (1995). Child abuse and neglect from an Indigenous Australian's perspective. Child Abuse \& Neglect, 19(3), 281-289. https://doi.org/10.1016/S0145-2134(94)00127-8

Smith, A. (2009). Indigenous Peoples and boarding schools: A comparative study. Secretariat of the United Nations Permanent Forum on Indigenous Issues. https://www.un.org/esa/socdev/ unpfii/documents/E_C_19 2009_crp1.pdf

Sommerlad, E. A. (1977). Aboriginal children belong in the Aboriginal community: Changing practices in adoption. Australian Journal of Social Issues, 12(3), 167-177. https://doi.org/10.1002/ j.1839-4655.1977.tb00597.x

Southern First Nations Network of Care. (2019). Annual report 2018-2019: Celebrating our youth. Southern First Nations Network of Care. https://www.southernnetwork.org/files/ SFNNCAnnualReport2018-19webRevised.pdf

Spence, N. (2004). Kinship care in Australia. Child Abuse Review, 13(4), 263-276. https://doi.org/ $10.1002 /$ car.854

Stanley, J., Tomison, A. M., \& Pocock, J. (2003). Child abuse and neglect in Indigenous Australian communities. Child Abuse Prevention Issues, 19, 1-31.

Statistics Canada. (2018, July 18). Canada (Country) [Table]. Aboriginal population profile. 2016 Census (Statistics Canada Catalogue no. 98-510-X2016001). https://www12.statcan.gc.ca/census-recensement/2016/dp-pd/abpopprof/details/ page.cfm?Lang $=E \&$ Geo $1=$ PR\&Code $1=01 \& D a t a=$ Count $\&$ SearchText $=$ Canada $\&$ Search Type $=$

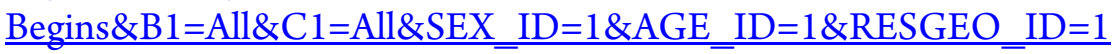

Stephenson, M. (2006). Closing the doors on the Maori schools in New Zealand. Race Ethnicity and Education, 9(3), 307-324. https://doi.org/10.1080/13613320600807717

Steering Committee for the Review of Government Service Provision. (2014). Child protection and Aboriginal and Torres Strait Islander children. https://aifs.gov.au/cfca/publications/childprotection-and-aboriginal-and-torres-strait-islander-children

Strega, S., \& Esquao, S. A. (Eds.) (2015). Walking this path together: Anti-racist and anti-oppressive child welfare practice (2nd ed.). Fernwood Publishing. 
Subcommittee on Indian Affairs. (1974). Committee on Interior and Insular Affairs, Senate, $93^{\text {rd }}$ Cong. http://www.narf.org/nill/documents/icwa.federal.lh/hear04087/hear040874.pdf

Summers, A., Wood, S., \& Donovan, J. (2013). Disproportionality rates for children of color in foster care (Report No. 2012-MU-MU-K001). National Council of Juvenile and Family Courts Judges. https://www.ncjfcj.org/publications/disproportionality-rates-for-children-of-color-infoster-care-fiscal-year-2015/

Swift, K. J. (1995). An outrage to common decency: Historical perspectives on child neglect. Child Welfare, 74(1), 71-91.

Tilbury, C. (2009). The over-representation of Indigenous children in the Australian child welfare system. International Journal of Social Welfare, 18(1), 57-64. https://doi.org/10.1111/j.1468$\underline{2397.2008 .00577 . x}$

Tilbury, C., \& Thoburn, J. (2009). Using racial disproportionality and disparity indicators to measure child welfare outcomes. Children and Youth Services Review, 31(10), 1101-1106. https://doi.org/10.1016/j.childyouth.2009.07.004

Timpson, A. M. (2010). First Nations, first thoughts: The impact of Indigenous thought in Canada. UBC Press.

Timpson, J. (1995). Four decades of literature on Native Canadian child welfare: Changing themes. Child Welfare: Journal of Policy, Practice, and Program, 74(3), 525-546. https://search.proquest.com/docview/213804850?pq-origsite=gscholar\&fromopenview=true

Tonmyr, L., Jack, S., Brooks, S., Kennedy, B., \& Dudding, P. (2009). Utilization of the Canadian Incidence Study of Reported Child Abuse and Neglect in First Nations child welfare agencies in Ontario. First Peoples Child \& Family Review, 4(1). https://fpcfr.com/index.php/FPCFR/ article/view $/ 75$

Trafzer, C. E., Keller, J. A., \& Sisquoc, L. (2006). Boarding school blues. Bison Books.

Trocmé, N. M., Tourigny, M., MacLaurin, B., \& Fallon, B. (2003). Major findings from the Canadian incidence study of reported child abuse and neglect. Child Abuse \& Neglect, 27(12), 14271439. https://doi.org/10.1016/j.chiabu.2003.07.003

Truth and Reconciliation Commission of Canada (TRC). (2015). The final report of the Truth and Reconciliation Commission of Canada: Vol. 5 Canada's residential schools: The legacy. http://www.trc.ca/assets/pdf/Volume_5_Legacy_English_Web.pdf

United Nations Committee on the Elimination of Racial Discrimination. (2017). Concluding observations on the combined twenty-first and twenty-second periodic reports of New Zealand (CERD/C/NZL/21-22). http://docstore.ohchr.org/SelfServices/FilesHandler.ashx?enc= 6QkG1d\%2FPPRiCAqhKb7yhstd7O\%2FNaHZmivtI5SO9x\%2B6zWMPcs8q996TjxPdK56I1 DeHvdN6JWCTgh5BkuJGnvQPtuyslx4KJGtoUtVtF5C4KyTrm8bFUtZz\%2FdtyDZy1xSpD6 


\section{fVa\%2FZLrNxeUq\%2F\%2BXYEIg\%3D\%3D}

van Krieken, R. (1999a). The barbarism of civilization: Cultural genocide and the 'Stolen Generations.' The British Journal of Sociology, SO(2), 297-315. https://doi.org/10.1111/j.14684446.1999.00297.x

van Krieken, R. (1999b). The 'Stolen Generations' and cultural genocide: The forced removal of Australian Indigenous children from their families and its implications for the sociology of childhood. Childhood, 6(3), 297-311. https://doi.org/10.1177/0907568299006003002

Vulnerable Children Act 2014, No. 40. https://www.legislation.govt.nz/act/public/2014/0040/63.0/ DLM5501618.html

Waechter, R. L., Wekerle, C., Leslie, B., Goodman, D., Wathen, N., \& Moody, B. (2009). Child protection services and university-based partnerships: A participatory action-based model for creating and sharing knowledge. First Peoples Child \& Family Review, 4(2). https://fpcfr.journals.publicknowledgeproject.org/index.php/FPCFR/article/view/148

Wahlquist, C. (2017). Indigenous children in foster care: 'These kids can't see their families if I don't help them.' https://www.theguardian.com/australia-news/2017/may/24/indigenouschildren-in-foster-care-these-kids-cant-see-their-families-if-i-dont-help-them

Waites, C., Macgowan, M. J., Pennell, J., Carlton-LaNey, I., \& Weil, M. (2004). Increasing the cultural responsiveness of family group conferencing. Social Work, $49(2), 291-300$. https://doi.org/ $\underline{10.1093 / \mathrm{sw} / 49.2 .291}$

Wallace, H. M. (1973). The health of American Indian children: A survey of current problems and needs. Clinical pediatrics, 12(2), 83-87. https://doi.org/10.1177/000992287301200207

Weaver, H. N. (1999). Indigenous people and the social work profession: Defining culturally competent services. Social Work, 44(3), 217-225. https://doi.org/10.1093/sw/44.3.217

Wells, S. J., Merritt, L. M., \& Briggs, H. E. (2009). Bias, racism and evidence-based practice: The case for more focused development of the child welfare evidence base. Children and Youth Services Review, 31(11), 1160-1171. https://doi.org/10.1016/j.childyouth.2009.09.002

White, R. B., \& Cornely, D. A. (1981). Navajo child abuse and neglect study: A comparison group examination of abuse and neglect of Navajo children. Child Abuse \& Neglect, 5(1), 9-17. https://doi.org/10.1016/0145-2134(81)90072-7

White, V. (2017). Disproportionality of American Indian children in foster care. https://sophia.stkate. edu/msw papers $/ 812$

Wien, F., Blackstock, C., Loxley, J., \& Trocmé, N. (2007). Keeping First Nations children at home: A few federal policy changes could make a big difference. First Peoples Child \& Family Review, 3(1). https://fpcfr.com/index.php/FPCFR/article/view/21 
Wildeman, C., \& Emanuel, N. (2014). Cumulative risks of foster care placement by age 18 for US children, 2000-2011. PloS One, 9(3), e92785. https://doi.org/10.1371/journal.pone.0092785

Wilson, M. (2015). Reflections on reconciliation. First Peoples Child \& Family Review, 10(2), 12-14. https://fpcfr.com/index.php/FPCFR/article/view/284

Worrall, J. (2006). Challenges of grandparent custody of children at risk in New Zealand. Families in Society: The Journal of Contemporary Social Services, 87(4), 546-554. https://doi.org/ $\underline{10.1606 / 1044-3894.3570}$

Yablon, M. (2004). The Indian Child Welfare Act Amendments of 2003. Family Law Quarterly, 38(3), 689-710. www.jstor.org/stable/25740482

Yeo, S. S. (2003). Bonding and attachment of Australian Aboriginal children. Child Abuse Review, 12(5), 292-304. https://doi.org/10.1002/car.817

Zhou, A. Z., \& Chilvers, M. (2010). Infants in Australian out-of-home care. The British Journal of Social Work, 4O(1), 26-43. https://doi.org//10.1093/bjsw/bcn058

Zufferey, C., Gibson, C., \& Buchanan, F. (2015). Collaborating to focus on children in Australian social work education. Social Work Education, 34(1), 32-45. https://doi.org/10.1080/02615479. $\underline{2014.940889}$ 